\title{
Double Bank Runs and Liquidity Risk Management
}

\author{
Filippo Ippolito José-Luis Peydró Andrea Polo Enrico Sette*
}

\begin{abstract}
By providing liquidity to depositors and credit-line borrowers, banks can be exposed to double-runs on assets and liabilities. For identification, we exploit the 2007 freeze of the European interbank market and the Italian Credit Register. After the shock, there are sizeable, aggregate double-runs. In the cross-section, credit-line drawdowns are not larger for banks more exposed to the interbank market; however, they are larger when we condition on the same firms with multiple credit lines. We show that, ex-ante, more exposed banks actively manage their liquidity risk by granting fewer credit lines to firms that run more during crises.
\end{abstract}

Keywords: Credit lines; Liquidity risk; Financial crisis; Runs; Basel III. JEL Codes: G01, G21, G28.

\footnotetext{
*Filippo Ippolito: Universitat Pompeu Fabra, Barcelona GSE and CEPR, filippo.ippolito@upf.edu, Ramon Trias Fargas 25-27, 08005, Barcelona, Spain, tel. +34 93542 2578; José-Luis Peydró: ICREA-Universitat Pompeu Fabra, Barcelona GSE, CREI and CEPR, jose.peydro@upf.edu, Ramon Trias Fargas 25-27, 08005, Barcelona, Spain, tel. +34 93542 1756; Andrea Polo: Universitat Pompeu Fabra and Barcelona GSE, andrea.polo@upf.edu, Ramon Trias Fargas 25-27, 08005, Barcelona, Spain, tel. +34 93542 2641; Enrico Sette: Bank of Italy, enrico.sette@bancaditalia.it, Via Nazionale 91, 00184, Rome, Italy, tel: +39 0647923772 (contact author). We thank Heitor Almeida, Tobias Berg, Claudio Michelacci, Steven Ongena, Richard Rosen, Andrei Shleifer, Jason Sturgess, Boris Vallee and seminar participants at Adam Smith Workshop in London, Financial Intermediation Research Society in Reykjavík, Csef-Igier Symposium in Capri, European Finance Association in Vienna, American Finance Association in San Francisco, Banca d'Italia, Ente Einaudi, HEC, Bocconi and UPF for useful comments and suggestions. Peydró acknowledges financial support from project ECO2012-32434 of the Spanish Ministry of Economics and Competitiveness and the European Research Council Grant (project 648398). The views of this paper are those of the authors and do not represent the views of Banca d'Italia or of the Eurosystem.
} 


\section{Introduction}

The financial crisis that started in 2007 was centered on wholesale liquidity problems at financial institutions. This was in stark contrast with previous financial crises in history, where bank runs were mainly coming from retail depositors (Cornett, McNutt, Strahan, and Tehranian, 2011; Gorton and Metrick, 2012; European Central Bank, 2012; Freixas, Laeven, and Peydró, 2015). The financial crisis hit European markets on August 9, 2007 when the interbank market dried up. Banks that relied more on interbank funding suffered a severe liquidity shock to the liability-side of their balance sheet. Moreover, there is some evidence that firms increased the drawdown on available credit lines after the failure of Lehman Brothers in September 2008 (Ivashina and Scharfstein, 2010), which implies a liquidity shock on the asset side of banks. In this paper we ask to what extent the drawdowns on credit lines are more intense for banks more exposed to the wholesale (interbank) funding liquidity shock, thereby leading to an asset and liability_-double — bank run, and whether banks do ex ante liquidity risk management to minimize this risk of double runs.

The provision of liquidity to both firms and depositors is at the heart of banking. Diamond and Dybvig (1983), among others, identify the existence of synergies between bank assets and liabilities. This explains why banks pair illiquid assets (loans), with liquid liabilities (retail and wholesale deposits) that are subject to runs. Kashyap, Rajan, and Stein (2002) emphasize the parallel between deposits and credit lines as both are subject to runs. They argue that, as long as deposit withdrawals and credit-line drawdowns are imperfectly correlated, offering both products allows them to economize on costly liquidity buffers. Moreover, Hanson, Shleifer, Stein, and Vishny (2015) argue that financial institutions with more fragile sources of funding (uninsured wholesale finance) should hold assets with lower 
liquidity risk, such as credit lines. ${ }^{1}$ On the other hand, the opinion of many commentators and the implications of several theoretical models indicate that, in the presence of moral hazard, weaker banks with less stable funding are prone to excessive risk-taking, e.g., by minimizing liquidity risk management (Freixas and Rochet, 2008). This debate highlights the importance of an empirical analysis of correlated (double) asset-liability bank runs as a test of the existing theory, as well as for the design of prudential policy and for a better understanding of financial crises.

In this paper we examine the following specific questions. Do banks suffer double runs? Do firms run on the credit lines granted by banks that are hit by a funding liquidity shock on their liabilities? And, before a liquidity shock, is there evidence of liquidity risk management by banks with more fragile liabilities in their granting of credit lines?

The empirical analysis of these questions presents serious challenges for a researcher. Identification requires the following three ingredients: a) a shock to bank funding liquidity that is exogenous and offers cross-sectional heterogeneity; b) a sample of firms with multiple simultaneous credit lines held at different banks, to isolate which bank a firm chooses to run on; c) an exhaustive credit register with the credit lines extended by banks, inclusive of relevant loan and firm variables (e.g., loan price and loan applications; firm leverage and size).

${ }^{1}$ Other theory papers also examine the synergies between bank assets and liabilities. Diamond and Rajan (2001) show that the fragility of bank deposits disciplines bank management, enhancing the value of illiquid bank loans. Rochet and Vives (2004) also show that interbank runs can discipline banks in their choice of investments. Gennaioli, Shleifer, and Vishny (2013) emphasize asset-side diversification and tranching to back safe liabilities. Other papers highlight only one aspect of banks: (i) lending to opaque firms thanks to a bank's ability in monitoring and screening (e.g., Diamond, 1984; Dell'Ariccia and Marquez, 2006); or (ii) the creation of bank deposits that are used as inside money (e.g., Gorton and Pennacchi, 1990; Stein, 2012). 
Our empirical strategy relies on the above three ingredients, each of which is critical for the identification of the effects that we investigate. As a shock to bank funding, we exploit the dry-up of the European interbank market in August 2007. This shock was exogenous to the Italian banking system and heterogeneous across banks, because banks differed significantly in their pre-shock interbank funding. ${ }^{2}$ As for data on credit lines, we have access to the comprehensive Italian Credit Register held at the Bank of Italy, which allows for a match between banks and firms at the level of each credit relationship. The depth and breadth of the database allows us to focus on firms with multiple credit lines simultaneously held at different banks. For these firms we can test whether a firm draws preferentially on the credit lines provided by banks that are affected more by the interbank shock. Although most firms have credit lines with more than one bank, for additional tests we also consider the broader spectrum of firms with a credit line from only one bank.

Before August 2007, spreads on unsecured interbank lending had remained stable at very low levels for several years. In August 2007, interbank spreads and volatility increased significantly, as shown in Fig. 1. The interbank market dried up on August 9, which led the European Central Bank (ECB) to inject almost 100 billion euros in liquidity into the system on that day. However, in 2007, the ECB did not provide full liquidity allotment (ECB, 2012), which only became available after the collapse of Lehman Brothers in September 2008. The 2007 crisis originated in the U.S. and was triggered by the exposure of investors to subprimerelated securities. The crisis spread to the European markets when this subprime exposure led BNP Paribas to suspend redemptions from three of its investment funds (Brunnermeier, 2009). This event caused a shock to the European interbank market. Notably, while in some

\footnotetext{
${ }^{2}$ Bank liquidity and fundamentals interact in bank runs (see Goldstein and Pauzner, 2005). Accordingly, in the analysis we use a pre-crisis measure of interbank funding, as change in interbank volume or pricing at the bank level after the shock may also be due to bank fundamentals.
} 
European countries there were credit and housing price bubbles somewhat similar to the US ones, this was not the case in Italy. ${ }^{3}$ The liquidity shock of August 2007 affected Italian banks with different intensities depending on their interbank funding. In our identification strategy, we exploit this heterogeneity in the cross-section of interbank funding before the crisis in conjunction with the time identification offered by the exogenous shock to the European interbank market.

The Credit Register of the Bank of Italy contains the credit lines granted to nonfinancial corporations in Italy. The richness of the database allows us to look at multiple credit lines that are extended simultaneously to one firm by different banks. The fact that simultaneous credit lines are common practice in Italy allows for the inclusion of firm fixed effects, which allows us to test whether a firm with multiple credit lines from different banks chooses to draw down from some specific banks (e.g., the banks with higher interbank funding). That is, whether the demand side (firm) chooses to withdraw from the supply side (banks), which is different from the credit supply literature (Khwaja and Mian, 2008).

The Italian Credit Register also contains data on loan pricing and on granting of loan applications, which are absent in most credit registers around the world. These additional loan characteristics are important to control for whether credit lines extended to a firm by different banks differ along potentially relevant dimensions (in particular, prices). We match the data on credit lines to firm-level information on size, leverage, liquidity, and $Z$-score, and to supervisory bank-level data on size, capital, return on assets, ownership, and liquidity. Analyzing firm observables is crucial to test ex ante (pre-crisis) liquidity risk management by

\footnotetext{
${ }^{3}$ Moreover, both the exposure to asset backed securities (see Bonaccorsi di Patti and Sette, 2012) and the exposure to the US and European countries with real estate bubbles, such as Spain and Ireland (see Bank for International Settlements data www.bis.org/statistics/), was low overall.
} 
banks that are more exposed to interbank borrowing. Controlling for bank characteristics is important because they may affect drawdowns, together with interbank funding.

We find the following results. After the shock to the European interbank market, a direct comparison of before and after the shock shows that there are sizeable double runs on bank assets and liabilities. We observe a sharp increase in drawdowns on credit lines and also a sharp reduction in interbank borrowing. In particular, we find an average increase of $16.70 \%$ of the drawdown amount between June and September 2007. During this period the change in the amounts of credit lines granted is close to zero, which implies that the variation in the ratio of drawn to granted (credit lines) comes entirely from drawdowns by firms on banks. ${ }^{4}$ Moreover, the aggregate withdrawals in the interbank market are approximately $22 \%$, and even larger for banks with greater borrowings from the interbank market before the crisis. In sum, after the European interbank freeze in 2007, banks in Italy experienced sizeable aggregate double bank runs.

Next, we analyze the cross-sectional variation, before and after the shock, using a difference-in-difference approach. We relate post-shock credit-line drawdowns to pre-shock exposure of banks to the interbank market. Are drawdowns in the crisis larger for banks that are ex ante more exposed to interbank funding liquidity risk?

In loan-level regressions, without any firm controls, we show that credit-line drawdowns are not larger for banks with higher interbank funding. We also find the same result if we collapse the database at the bank level. That is, unconditionally on any firm

\footnotetext{
${ }^{4}$ The change in drawdowns over the amount of credit lines granted is $4.5 \%$ in the period between June and September 2007, versus a very close to zero change in the period between March and June 2007. In addition, if we aggregate all the credit lines, the change in the summer of 2007 is reduced to $3 \%$ in credit-line drawdowns, as this variation is dominated by a few very large firms that tend to draw down less in the crisis as compared to smaller firms.
} 
characteristic, pre-shock cross-sectional interbank exposure is unrelated to post-shock creditline drawdowns.

However, it is possible that before the shock banks with higher interbank market exposure may have granted credit lines to a different set of firms. Therefore, to examine the presence of double bank runs in the cross-section, we need to control for both observable and unobservable firm characteristics. When we augment the loan-level regressions with firm observable characteristics, we find that the coefficient associated with the pre-shock exposure to the interbank market is positive and relatively large. When we also control for unobservable firm characteristics, by including firm fixed-effects, the above coefficient doubles in size and becomes highly statistically significant. In other words, this means that conditional on within-firm variation, after the shock firms with multiple credit lines draw down more from banks that have larger pre-shock interbank exposure. For example, a firm that has (at least) two credit lines will draw down more from the banks with higher interbank borrowing. Moreover, the significant effect on drawdowns is present both as a percentage of granted credit (change in drawdowns over granted) and in absolute terms (change in drawdowns).

We run placebo tests that go back to 2006, and show that these effects are not present before the shock. In addition, we control for credit-line characteristics, and test whether credit lines of banks with different interbank funding have different lending conditions. We show that drawdowns on credit lines are driven neither by different pricing (in levels and changes), nor by other contractual conditions attached to the line of credit.

The results suggest that the credit-line run on banks is justified by the fearsubsequently realized — that banks with higher interbank funding may restrict the supply of credit to firms. Borrowers do not experience an immediate reduction in the supply of credit lines but, in the months following August 2007, banks with higher pre-crisis interbank 
funding tighten relatively more than other banks the supply of loans to new applicants. This result is obtained by analyzing firms that are applying for loans to multiple banks simultaneously. Moreover, our main result on higher credit-line runs on banks with higher pre-crisis interbank funding is reinforced when firms are more leveraged and smaller, and when banks are less liquid and smaller. Thus, the credit-line run was common to all firms and banks, but it was relatively stronger for financially constrained firms and banks.

Next, we shift our attention to how banks manage the risk of double runs. Do banks with higher interbank funding take ex ante actions to contain the risk of asset-side runs? Our results indicate that they do, and that liquidity risk management can neutralize the crosssectional impact of correlated double runs. As discussed above, banks with higher interbank funding do not suffer higher drawdowns during the crisis. This result indicates that (unconditionally to firm characteristics) banks with higher pre-crisis interbank funding do not suffer larger credit-line runs than the average bank. However, from our disaggregated loanlevel regressions-conditioning on borrower (observable and unobservable) characteristicswe also know that higher ex ante cross-sectional interbank funding leads to larger ex post drawdowns on credit lines.

One potential way to read the above results is that banks are aware of the risk of double bank runs, and, therefore, they actively manage the risk of asset-side liquidity shocks by selectively offering credit lines to borrowers that, conditional on both unobservable and observable characteristics, are less prone to drawdowns in crisis times. To test this hypothesis, we analyze the period immediately before the crisis and find that banks with higher interbank funding: a) grant fewer credit lines in general (extensive margin), and even less so to financially constrained firms (that run more in crisis times); b) conditionally on granting a line, offer lower amounts (intensive margin). In summary, our results indicate that banks manage the risk of double runs through the selective granting of credit lines, thus mitigating 
the cross-sectional effect of double runs during the crisis. Our findings imply that such liquidity risk management is effective in that banks with higher interbank risk do not suffer more credit-line runs than banks with lower interbank risk.

We contribute to the literature in three ways. Firstly, we test empirical predictions of the theoretical literature studying the synergies between bank assets and liabilities, in particular, related to liquidity risk. The existing literature on this topic has analyzed bank liquidity risk at the bank or firm level. We show that proper identification requires an analysis at the credit-line level. Kashyap, Rajan, and Stein (2002) show that banks that rely more on demand deposits are able to grant more credit lines to borrowers. ${ }^{5}$ Gatev, Schuermann, and Strahan (2009) find a diversification benefit between the two activities: bank-stock return volatility increases with unused commitments, but the increase is smaller for banks with high levels of demand retail deposits. Gatev and Strahan (2006) show that when market liquidity dries up and commercial paper rates rise, banks may experience deposit inflows. However, due to deposit insurance, funding liquidity risk for banks is mostly associated with wholesale deposits, rather than with retail deposits (Brunnermeier, 2009; European Central Bank, 2012). ${ }^{6}$

An insightful recent paper, Santos (2014), analyses credit-line drawdowns at the loan level. He finds that during a recession banks with higher net charge-offs in a given year, experience credit-line drawdowns and deposit withdrawals in the following year. Our paper differs from Santos along two dimensions: 1) we address a related but different question; 2) we use a different identification strategy and a more comprehensive data set. In this paper we

\footnotetext{
5 Acharya, Almeida, and Campello (2013) and Acharya, Almeida, Ippolito, and Perez (2014) find that
} firm characteristics matter for access to credit lines.

${ }^{6}$ For evidence on the dynamics of bank runs by retail depositors, see Iyer and Puri (2012), Brown, Morkoetter, and Guin (2014), and Iyer, Puri, and Ryan (2015). 
investigate how liquidity risk stems from both sides of a bank's balance sheet and how banks manage this risk. Santos does not identify pure liquidity risk and does not analyze risk management. As a measure of bank shock, Santos uses the change in bank losses. Therefore, his analysis of runs is not purely on liquidity risk, but more generally on bank fundamentals. Instead, in our paper the shock to a bank comes from an exogenous Europe-wide shortage of interbank funding. Our shock is exogenous to a bank's balance sheet and it is strictly related to liquidity. Therefore, we show double bank runs stemming from a pure bank liquidity shock and how this shock affects both the asset and liability sides of banks. Further on the issue of identification, Santos does not use firm fixed effects in his analysis, which we show to be very important to address the effects of endogenous matching between borrowers and lenders: banks with higher net charge-offs may have lent to riskier borrowers that draw more on credit lines in a recession, because they are more financially constrained. Moreover, our results show that firm fixed effects are crucial for identifying from which bank a firm chooses to withdraw on their different lines at any given time, which in turn is necessary to properly identify runs. $^{7}$

The second contribution to the literature is to provide evidence that banks are aware of the risk of a double-liquidity shock and manage this liquidity risk by selecting ex ante borrowers that run less during a crisis. This finding is consistent with the recent theoretical work of Hanson, Shleifer, Stein, and Vishny (2015), who show that financial institutions with less stable sources of funding select assets with lower liquidity risk. Our results are not

${ }^{7}$ In terms of data, Santos (2014) uses the Shared National Credit (SNC) database, which contains only syndicated loans over 20 million dollars and yearly data that are not ideal for the analysis of a short-term phenomenon like a run. Moreover, with yearly data one cannot accurately compute the evolution of the ratio of drawn-to-granted credit, because the amount of the granted credit may be subject to unobservable renegotiations during the year. 
consistent with the prevailing moral hazard view in banking that predicts risk shifting (e.g., by carrying out minimum levels of risk management) by more fragile banks (see Freixas and Rochet (2008) for an overview). The absence of bank-level results may be interpreted as evidence of lack of correlation between runs on a bank's assets and liabilities. However, our identification and results show that this is not the case and that the absence of bank-level results is due to risk management by banks.

Third, we contribute to the recent literature that examines credit supply by banks using firm fixed effects in loan-level data (Khwaja and Mian, 2008). Differently from this literature, firm fixed effects in our setting imply that the firm (the credit demand side)—having credit lines from several banks (the supply) — chooses to draw down from the banks with higher interbank funding. Importantly, we show that banks with higher liability risk grant fewer credit lines to firms with higher liquidity risk. This explains why the inclusion/exclusion of firm fixed effects dramatically affects our results, whereas in most papers about credit supply, firm fixed effects do not matter for the key results (see Khwaja and Mian, 2008; Schnabl, 2012; Cingano, Manaresi, and Sette, 2013; among others).

The rest of the paper is organized as follows. Section 2 describes the data. Section 3 explains the identification strategy. Section 4 provides the empirical results. Section 5 concludes and highlights the implications for prudential policy.

\section{Data}

We construct our sample by merging data from three sources: a) the Italian Central Credit Register which is a supervisory, centralized data set managed by the Bank of Italy, the supervisor of the Italian banking system, that records the credit exposure of resident banks to nonfinancial borrowers, including credit volume and, uniquely, price and loan applications; b) 
the Italian Supervisory Reports which contain data on individual and consolidated balance sheets for Italian banks; c) Cerved which contains the accounting data on Italian nonfinancial corporate borrowers. ${ }^{8}$ Borrowers are reported in the Central Credit (CR) Register if they have loans of at least 75,000 euros, including guarantees. Credit granted and credit disbursed (drawn) are disaggregated by loan type (loans backed by account-receivables, term loans, credit lines). In our sample we consider all bank-firm relationships recorded in the CR as of June 2007. We then obtain data on credit granted and drawn within these bank-firm relationships in June 2007, September 2007, December 2007, and in March 2007 and December 2006 for the pre-crisis period.

In the sample we mainly include firms that have at least two outstanding (drawn or not) credit lines from two different banks. ${ }^{9}$ Out of the total credit given to the corporate sector, the share of credit given to firms who borrow from at least two banks is above $85 \%$. This yields a sample of 472,153 firm-bank relationships in 2007, which corresponds to 137,078 firms. Conditional on having credit lines from at least two banks, firms in our sample have on average credit lines with 3.4 banks. We aggregate all the credit lines that a firm has with the banks of the same group. This step is necessary for three reasons: first, lending policies are typically decided at the group level; second, interbank borrowing is usually conducted by one or few entities within a group, and funds are redistributed to the rest of the group through the internal capital market; third, regulatory capital ratios are imposed also at

${ }^{8}$ Cerved collects official balance sheet data deposited by firms to the Chambers of Commerce, as required by the Italian law. Cerved is a member of the European Committee of Central Balance-Sheet Data Offices.

${ }^{9}$ When we look at aggregate effects at the bank level, we also include firms with a credit line from only one bank. 
the group level. ${ }^{10}$ Table 1 reports descriptive statistics of our variables. Variables are defined in the Appendix.

\subsection{Credit-line variables}

We build our measure of "run" on credit lines by constructing the ratio of drawn over granted credit for each credit line, and compute the difference in this ratio between June and September 2007. To test whether the dynamics of the drawn-to-granted ratio is driven by drawn credit or by granted credit, we also compute growth rates of the two raw variables. Growth rates of drawn (granted) credit lines are computed as changes in the log of drawn (granted) between June and September. Table 1 reports descriptive statistics for the 472,153 credit lines included in the sample. The descriptive statistics in the table reveal that on average there was an increase in drawdowns on credit lines after the liquidity shock. We discuss these statistics in greater detail in the section dedicated to results.

We also compute a set of bank-firm relationship variables as of June 2007. We compute the share of credit of bank $j$ out of total credit to firm $i$ (share). This is a measure of the exposure of a bank to a firm, and of the relative importance of a lender as a funding source for a firm. We compute a dummy variable equal to one if firm $i$ has past-due loans with bank $j$ (past due). For the credit line granted to firm $i$ by bank $j$, we consider also the drawn-togranted ratio at the beginning of the period (drawn/granted).

\section{TABLE 1 about here}

\footnotetext{
${ }^{10}$ We also control for mergers and acquisitions to keep track of credit lines when bank identifiers change.
} 


\subsection{Firm characteristics}

Credit-line data are then matched to firm accounting variables obtained from Cerved. The data for firms refer to the fiscal year 2006. This is to ensure that firm data are not affected by the shock of August 2007, and to guarantee that such data were observable to banks in June 2007. The firm characteristics that we consider include size, risk, liquidity, and leverage. Table 1 shows descriptive statistics of the 137,078 firms included in the sample. ${ }^{11}$ The firms in our sample have on average about 9.86 million euros in assets, with a large standard deviation, because most of them are of small and medium size by international standards (the median is about 2.13 million euros). Risk is measured with Altman's Z-score. The average Zscore is 5.59 . The percentage of liquid assets in the balance sheet is $6.85 \%$. Finally, firms in our sample have an average leverage ratio of $26.29 \%$.

\subsection{Bank characteristics}

Data on the balance sheet of banks are obtained from the Supervisory Reports filed with the Bank of Italy and are measured at the beginning of each period. If the bank belongs to a banking group, we use the data of the corresponding consolidated top-tier entity. ${ }^{12}$ Our proxy for bank exposure to the liquidity shock of August 2007 is the share of gross interbank funding (interbank), measured as the ratio of total borrowing from other banks to total assets. In the definition, we include deposits and repos from other banks, but we exclude deposits from the ECB or other national central banks. We compute interbank borrowing at the group level for banks that belong to the same group, meaning that flows among entities of the same

\footnotetext{
${ }^{11}$ For each variable we have a different number of firms depending on the availability of data.

${ }^{12}$ We exclude branches of foreign banks from the sample because we do not observe the data for the
} parent company. 
group are netted out. We use gross interbank borrowing, instead of net borrowing, as the former better captures the extent to which a bank is exposed to a run on its liabilities during the crisis.

To isolate the effect of a bank's exposure to the interbank market from other channels, we control for several other bank characteristics. We compute the return on assets $(R O A)$ as net income divided by total assets. ROA is potentially an important control, because when market conditions are unfavorable banks find it costly to raise external capital, which means that equity increases primarily through retained earnings. We compute a bank's capital ratio as equity divided by total assets. Equity is defined as equity (shares subscribed, book value of equity) plus retained earnings. Other forms of capital, like subordinated convertible securities, are excluded. We compute a bank's liquidity ratio as the sum of cash holdings and sovereign bonds divided by total assets. Bank size is measured by the logarithm of total assets ( $\log$ assets). We also include a dummy variable that equals one if the bank is a mutual financial institution (mutual bank), and zero otherwise.

Table 1 reports descriptive statistics for the 531 banks included in the sample. ${ }^{13} \mathrm{We}$ weight each bank by its size. The average interbank funding is $13.36 \%$. The percentage of liquid assets in the balance sheet is $6.22 \%$, the percentage of equity is $7.49 \%$, and the average ROA is $1.42 \%$. The size of banks varies substantially, as we have both large multinational groups and local banks. The share of credit with mutual institutions is $9.10 \%$.

\subsection{Loan applications}

${ }^{13}$ The number of banks increases from 529 in December 2006 to 531 in June 2007 due to the entry of two banks in the market. These two banks did not post balance sheet data in December 2006 since they were not active in 2006. 
We obtain data on loan applications by potential borrowers to banks from the records of information requests held at the Credit Register, which contains data on the applicant's overall outstanding debt and default status within the banking system. The Credit Register records the request together with a code that identifies new applications, as first information requests, and only banks facing a loan application can request this information. We compute each first information request submitted by each bank to each firm in the Credit Register. There is no field indicating whether the bank subsequently granted a loan or not. To obtain a measure of the granting of a loan application, we check in the Credit Register if the bank granted any credit to the applicant in the three months following the loan application.

We distinguish before and after the liquidity shock of summer 2007. For the period before the shock, we record a loan application as granted if it was submitted to a bank between January and April 2007, and if we observe that the bank grants credit to the applicant between January and July 2007. For the period after the shock, we follow the same procedure but look at applications between September and December 2007, and granting decisions between September 2007 and March 2008. ${ }^{14}$ Table 1 shows descriptive statistics of the loan applications included in the sample. We find that there is a similar percentage rate of granting of applications in the two subperiods $(27.65 \%$ in the post-crisis and $27.57 \%$ in the pre-crisis period).

\section{Identification strategy}

In this section we discuss the identification for the cross-sectional variation in runs before and after the European interbank shock. In particular, we address the following

${ }^{14}$ We use monthly rolling windows. For example, for the applications that take place in September, we look at the decision to grant credit in the period between September and December. 
question: do firms with multiple credit lines from different banks draw down preferentially from some banks rather than others, when a funding liquidity shock hits the banks? In particular, we expect firms to draw down preferentially from the banks that suffer the most from the liquidity shock, in anticipation of a more severe credit tightening by these institutions. When addressing this question, there are two main identification challenges.

First, bank liquidity problems could stem from worse fundamentals, in particular, related to the asset side of the balance sheet. Therefore, it is necessary to have an exogenous shock to bank liquidity that is unrelated to fundamentals. In addition, it is important to use a shock for which there is sufficient cross-sectional heterogeneity in how it affects banks, to exploit an identification strategy based on differences-in-differences: before versus after the shock, with respect to banks more or less affected by the shock.

Second, one needs an exhaustive credit database, which covers all the existing credit lines extended by different banks to each firm. Only with this level of completeness in the data, it is possible to examine on which line a firm chooses to draw down. This implies that the analysis must be carried out at the credit-line level, accounting for firm fixed effects. In our setting, borrower fixed effects have a different interpretation than in the literature on credit supply (Khwaja and Mian, 2008). In our case, conditioning on firm fixed effects, the coefficient of the variable interbank captures the specific change in demand of credit by a borrower, rather than the supply of credit by a bank, because the choice to draw down on a credit line is initiated by borrowers, not by banks. It is also important to control for the observable characteristics of the credit line, as credit lines could have different contractual terms, and most importantly different pricing (measured as spread over base rate). These contractual differences could drive the firm's choice to draw down on one line rather than another, and hence it is a channel that we need to control for (for example, by checking whether for the same firm at the same time, the credit lines from banks with different 
interbank exposure have a different level (or change in) loan pricing). It is also important to employ data at quarterly rather than yearly frequency, as to better identify the timing of the drawdown decision by the firm.

Italy offers an excellent setting for our empirical analysis because it allows us to examine the effects of the freeze out of the European interbank market in August 2007 in a country that was not experiencing a credit or a real estate bubble, and that has a unique and exhaustive data set contained in the Italian Credit Register, itself matched to bank- and firmlevel data.

\section{FIGURE 1 about here}

\subsection{A shock to wholesale (interbank) funding}

As a measure of liquidity shock at the bank level, we use the interbank funding ratio (interbank). This source of wholesale funding for banks dried up abruptly in the aftermath of the events that took place at the beginning of August 2007. The illiquidity in this market was mainly driven by a sharp increase in perceived counterparty risk (Brunnermeier, 2009; Iyer, Peydró, da-Rocha-Lopes, and Schoar, 2014). Fig. 1 shows that the spread between the rate on unsecured interbank transactions (Euribor) and that on secured ones (Eurepo) increased sharply in August 2007, marking the start of the financial crisis. The spread between the two rates increased dramatically from 10 basis points, until it reached 70 basis points.

The immediate cause of the shock that affected the European interbank market was the decision of BNP Paribas to renege capital redemptions by investors from two of its investment vehicles that were exposed to the U.S. subprime mortgage market (Brunnermeier, 
2009). This event was related to adverse developments in the market for securitized subprime mortgages. However, importantly for our identification strategy, neither were the developments in the subprime market related to the conditions of the assets held by Italian banks or to the Italian economy more generally, nor did Italy have a credit or real estate bubble as in Ireland or Spain. The events of August 2007 represented an unexpected shock to wholesale markets for liquidity, as argued in several accounts of the crisis (Brunnermeier, 2009; Rajan, 2011; Gorton, 2012; ECB, 2012; among others). ${ }^{15}$ Moreover, the European Central Bank did not provide unlimited provision of public liquidity in August 2007, as it did in mid-October 2008 during the post-Lehman financial crisis, and hence problems in the private market of liquidity could not be perfectly neutralized with public liquidity.

After the European interbank shock, there were aggregate withdrawals in the Italian interbank market of approximately $22 \%$ (as Table 1, Panel A, shows). Next, we test whether banks that relied more on interbank funding before the shock were hit harder by the liquidity shock of August 2007. In Table 2 we run regressions at the bank level for the change in interbank funding between June and December 2007 (crisis time) and between December 2006 and June 2007 (pre-crisis time), as a function of bank characteristics (respectively observed in June 2007 and in December 2006). ${ }^{16}$ Our results show that-after the liquidity shock of August 2007-the banks that were ex ante more exposed to the shock in interbank funding markets experienced a larger drop ex post in interbank deposits. However, we do not observe a drop in interbank deposits in the pre-crisis period. ${ }^{17}$ All in all, results suggest that after the shock to the European interbank market, there is a significant reduction in interbank

\footnotetext{
${ }^{15}$ See also Bonaccorsi di Patti and Sette (2012) for an account of the impact of the crisis in Italy.

${ }^{16}$ Data on bank balance sheet variables are available semiannually.

${ }^{17}$ In the Appendix, we report a related table (A5) where the dependent variable is the change in the logarithm of interbank deposits and we find similar results.
} 
borrowing, and even larger for banks with greater borrowings from the interbank market before the crisis.

\section{TABLE 2 about here}

Having identified the source of the liquidity shock to banks, we then need to relate it to the behavior of borrowers. The main variable of interest is the change in the ratio between the amount of credit line drawn by the firm and the amount granted to the firm by the bank. We explore whether the change in the ratio is higher for the credit lines granted by banks with higher exposure to the interbank market. Our period of interest is between July and September 2007. These months span over the exogenous interbank liquidity shock that took place in August 2007.

Our working hypothesis is that, after August 2007, firms became worried that credit would be reduced as a result of the liquidity problems that banks were facing due to their exposure to the interbank market. This is based on the assumption that firms were able to identify banks with more fragile funding structures. We believe that this hypothesis is plausible for the following reasons. First, the exposure to the interbank market is easily obtainable from the balance sheet of both listed and non-listed banks, because banks publish their financial accounts on their websites. Second, in its coverage of the crisis, the Italian press repeatedly stressed the role of interbank funding as a source of fragility for banks. ${ }^{18}$ Iyer

\footnotetext{
${ }^{18}$ Media coverage of the crisis stressed the role of interbank funding as a source of fragility for banks.
} According to La Repubblica, the second best selling newspaper in Italy: "The implosion of Northern Rock shakes even the final certainties... The only fragility of Northern Rock is that it relied on interbank funding, i.e. on loans from other banks," 17/9/2007. L'Espresso, a widely read magazine, wrote: "this is the first severe crisis 
and Peydró (2011) provide an example of a bank run in India, which shows that even relatively financially unsophisticated retail depositors are able to identify even the interbank exposure of their banks to a failed bank. ${ }^{19}$ This evidence suggests that, at the time of the crisis, it is reasonable to believe that firms were, or became aware, of the fragility of their lenders due to exposure to the interbank market.

\subsection{The empirical model}

Formally, we estimate the following model:

$$
\Delta\left(\frac{\text { Drawn }}{\text { Granted }}\right)_{i, j}=\beta_{1} \text { interbank }_{j}+\alpha_{i}+X_{j}^{\prime} \beta_{2}+Z_{i, j}^{\prime} \beta_{3}+\varepsilon_{i, j}
$$

The dependent variable in the regression is the change in the ratio of drawn to granted for a credit line by bank $j$ to firm $i$ between June and September 2007, for credit lines that were already granted in June. If firms draw down preferentially on the credit lines granted by banks that are more exposed to the liquidity shock, the coefficient of interbank, $\beta_{1}$, should be positive and significant. As we will discuss in more detail below, the potential run requires that the increase in the ratio of drawn to granted is driven by an increase in the numerator, rather than by a decrease in the denominator. In other words, the run requires a change that is driven by the demand for credit by firms, rather than by a reduction in supply of credit by

in which the interbank market is the main character," 21/9/2007. Il Sole 24 Ore, the leading financial newspaper, reports: "Italian banks are not immune to the crisis... The dry-up of liquidity in interbank markets...the sharp rise in the cost of funding are symptoms of a contagious disease which hit the banking system," 14/9/2007. Finally, according to Il Mondo, a financial magazine: "Interbank rates skyrocketed after the Subprime crisis....and this may translate into higher cost of funding for banks," 28/9/2007.

${ }^{19}$ In Iyer and Peydró (2011) depositors know about the interbank exposure of their bank to a failed bank partially through voluntary disclosure by banks, partially through monitoring (Calomiris and Kahn, 1991), and partially via rumors and word-of-mouth (Kelly and Grada, 2000; Iyer and Puri, 2012). 
banks. Additionally, we expect $\beta_{1}$ to be significant only in the immediate aftermath of the shock and not before.

A key feature of our identification strategy is the inclusion of firm fixed effects $\left(\alpha_{i}\right)$. Firm fixed effects can only be accounted for if one examines firms with multiple simultaneous credit lines granted by different banks. Accounting for firm fixed effects in the sample of firms with multiple credit lines allows us to control for relevant, yet unobservable, characteristics that may affect a firm's behavior with respect to drawdowns, and that are unrelated to bank characteristics (for example, lower cash flows or higher investment opportunities and thus higher need of external funding). Note that in a model without firm fixed effects, the estimate of $\beta_{1}$, which we refer to as $\hat{\beta}_{1}^{O L S}$, is unbiased only if the correlation between the exposure of a bank to the interbank market and the unobservable firm characteristics that may drive drawdowns is zero. More precisely, the estimated coefficient $\hat{\beta}_{1}^{O L S}$ is biased upward if the above correlation is positive, and downward otherwise. Notice that the correlation is negative when banks with higher interbank funding are matched to firms with lower liquidity needs, possibly because these banks grant more credit lines to these types of firms to reduce double liquidity risk. The estimate of $\beta_{1}$ in a model with firm fixed effects, $\hat{\beta}_{1}^{F E}$, provides an unbiased estimate of whether a firm in a given quarter chooses to draw down more from banks with higher interbank borrowing.

In our specification, we also include several bank controls, $X_{j}$, such as a bank's liquid assets, its capital ratio, its size, and a dummy for whether the bank is a mutual institution (liquidity, capital ratio, log assets, and mutual bank). These bank-level controls are meant to isolate the effect of a bank's exposure to the interbank market from other possibly relevant bank characteristics that may be related to drawdowns. The model also includes the relationship firm-bank variables, $Z_{i, j}$ (share, past-due, and drawn/granted) between banks and firms, which we have described in the previous section. These controls include the share of 
credit lines that a firm has outstanding from each of bank, whether a firm has credit past its maturity, and the ratio of drawn to granted on credit lines that a firm has in June 2007. These are important controls because firms may draw down differently from the banks with which they have a stronger relationship, or if they have committed previous credit delinquencies.

One possible concern when using the specification provided in Eq. (1) is that the ratio of drawn to granted for credit lines can increase for two reasons: because a firm draws down on the credit lines during the period June-September, or because during this period the amount of credit granted to a firm drops. To disentangle these two dynamics, we also run Eq. (1) using as dependent variables $\Delta \log (\text { drawn })_{i, j}$ (and, then, $\left.\Delta \log (\text { granted })_{i, j}\right)$, which is the change in the logarithm of the amount drawn by firm $i$ from bank $j$ between June and September 2007 (and respectively, the change in granted credit lines by bank $j$ to firm $i$ ). If the increase in the ratio of drawn to granted is due to an acceleration of drawdowns by firms, we expect the coefficient of interbank to be positive and significant in the specification with $\Delta \log (\text { drawn })_{i, j}$ as a dependent variable. Given our main interest in interbank funding and the variation in the data, we double cluster standard errors at the bank and firm levels. Another possible concern when using the specifications with logarithms is that we do not include in the sample the credit lines where the amount granted is zero in either June or September. Therefore, for robustness, we also measure the increase in drawn amounts by looking at the amount of drawn credit divided by the total assets of the firm.

We start from a model which includes only interbank and bank controls, then we include observable firm characteristics and firm-bank variables and, finally, we include also firm fixed effects as in Eq. (1). Our main analysis is based on this last richer specification.

The difference in the coefficients between the specification in Eq. (1) and the one without controlling for firm observable or unobservable characteristics will provide initial evidence whether banks select firms with different liquidity risk, i.e., whether they do 
liquidity risk management, another key question in our paper. Moreover, in the last section, we will directly test the risk management behavior by banks in their granting of credit lines in the period before the crisis.

\section{Results}

In this section we present and discuss the results. First, we present the overall evidence of the double bank runs after the European shock, as compared to before. We then move to the cross-sectional analysis (before and after the shock), first, without controlling for any firm characteristics, and then controlling for firm (observable and unobservable) characteristics. We also analyze some further firm and bank heterogeneity and why firms may run on banks with higher funding liquidity risk. Finally, we analyze data from before the crisis to test liquidity risk management by banks.

\subsection{Double runs on credit lines and interbank deposits}

The descriptive statistics in Panel A of Table 1 reveal that, after the European interbank shock, there are important double runs on bank assets and liabilities. On average, banks suffered an increase in the drawdowns on credit lines after the liquidity shock. Between June and September 2007, the mean increase in the logarithm of drawn amount is $16.70 \%$ (which corresponds to a percentage change in the underlying variable of $18.17 \%$ ), while in the three months before the increase was $2.04 \%$ (which corresponds to a percentage change in the underlying variable of $2.06 \%$ ). On the contrary, the change in the granted amounts is close to zero in both periods. That is, the whole variation entirely comes from drawdowns of nonfinancial firms to banks after the European interbank shock. Between June and September 2007, the mean change of the drawn-to-granted ratio is $4.56 \%$, which corresponds to more 
than $10 \%$ of the average quarterly drawn-to-granted ratio prior to the crisis. As a term of comparison, the mean change of the drawn-to-granted ratio between March and June 2007 is $0.21 \%$. Finally, as explained also in Section 3.1 where we discussed the interbank shock, results suggest that there are aggregate withdrawals in the interbank market of approximately $22 \%$. And not surprisingly, even more for the banks that were borrowing more ex ante from the interbank market (and are thus more exposed during the crisis) as Table 2 shows. As a consequence, looking at the time series before and after the European interbank freeze in 2007, banks in Italy experienced sizeable double bank runs.

\subsection{Cross-sectional analysis of runs on credit lines unconditional to firm characteristics}

In this section, we examine bank runs by looking at the cross-sectional relation between drawdowns on credit lines by firms after the shock and pre-crisis exposure to the interbank market of banks. We carry out the analysis both at the loan level and at the aggregate bank level. The results are reported in Panels A and B of Table 3.

In Panel A we regress the change in the drawn-to-granted ratio between June and September 2007 on the exposure of a firm's lender to the interbank market. We control for a set of bank characteristics that include liquidity, capital ratio, ROA, size measured as the log of a bank's assets, and for whether a bank is a mutual institution or not. We do not control for observable firm characteristics, or for bank-firm relationship level variables, or for firm fixed effects. We find that a bank's interbank exposure is not related to drawdowns on credit lines during the period of interest. This is true using either Ordinary Least Squares (OLS) or Weighted Least Squares (WLS), where the weights are the logarithm of the granted amount of credit line. WLS are important to gauge aggregate effects at the bank level considering that larger credit lines matter more. 
Next, in Panel B we aggregate our results at the bank level. For each bank we calculate the change in the logarithms of the drawn amounts of all the credit lines offered to its borrowers. ${ }^{20}$ Changes are computed over the period June 2007-September 2007 and March 2007-June 2007. The coefficient of interbank in both columns of Panel B is not significantly different from zero. This implies that-in the aggregate-banks with higher interbank exposure did not suffer a higher level of drawdowns during the crisis than other banks in the sample.

Altogether, Table 3 reveals that—unconditionally on firm characteristics—banks with higher pre-crisis interbank funding do not suffer larger credit-line runs than the average bank.

TABLE 3 about here

\subsection{Cross-sectional analysis of runs on credit lines conditional to firm characteristics}

Our results so far suggest that there is not a cross-sectional association between the asset and liability side of banks after the shock; i.e., banks with higher pre-crisis interbank funding (which are more negatively affected in the crisis for funding liquidity) do not suffer larger credit-line runs than the average bank. One explanation could be that banks with higher interbank exposure may have granted ex ante credit lines to different type of firms, and thus, in order to understand double bank runs in the cross-section, we need to control for firm characteristics, both observables and unobservables. Therefore, in this section we analyze the loan-level regressions conditioning on firm observable and unobservable characteristics.

\footnotetext{
${ }^{20}$ In this table the number of banks is higher than in other tables (538 instead of 531) because we include all firms in the database, including those with only one credit line. There are seven banks in the sample that offer credit lines only to firms with just one bank relationship.
} 
In Table 4, the dependent variable in all specifications is the change in the drawn-togranted ratio between June and September 2007. The first column reports the same result shown in Table 3 Panel A, reproduced here for easier comparison. In the second column we include a set of observable firm characteristics (leverage, risk, liquidity, and size) and a set of relationship firm-bank variables (share, past due, and drawn/granted). In the third column we also include firm fixed effects. Columns 1-3 use Ordinary Least Squares (OLS), while columns 4-6 report the same specifications as in column 1-3 using Weighted Least Squares (WLS), where the weights are the logarithm of the granted amount of credit line.

A comparison across column 1-3 (respectively, 4-6) shows that there are significant differences in the coefficient of interbank. In columns 1 and 4, as we saw above in Table 3 Panel A, the coefficient is slightly negative but it becomes positive and high in columns 2 and 5 when we account for firm observable characteristics. In columns 3 and 6, when we also include firm fixed effects, the coefficient doubles in size (from the one with only firm observables) and becomes highly statistically significant. This means that during the period between June and September 2007, for a firm with two (or more) lines provided by different banks, the firm draws down (the percentage of drawn to granted increases relatively) more from the bank with higher exposure to the interbank market. The non-significance of the coefficients in the models without firm fixed effects shows the importance of including fixed effects for identifying the double bank run in the cross-section.

The sign and significance of the coefficients of the observable firm characteristics that we include as control variables in columns 2 and 5 are all intuitive. Higher drawdowns during the liquidity shock of August 2007 come from firms with higher leverage and risk, and lower liquidity and size. Insofar as these characteristics capture the extent of firm's financial constraints, we conclude that more financially constrained firms increased the drawdown on their credit lines more than the average firm. One possible interpretation of this finding is that 
financially constrained firms face stiffer consequences in case of a reduction of credit by their banks, because they have few or no other sources of funding that they can turn to. For this reason, the results suggest that financially constrained firms utilize their credit lines while they are still available.

TABLE 4 about here

\subsection{Full-fledged analysis of runs on credit lines including firm fixed effects}

In Table 5 we fully analyze the results of our main tests when firm fixed effects are included. In column 1, we replicate column 3 of Table 4 . The dependent variable is the change in the ratio of drawn to granted credit lines between June and September 2007, expressed in percentage points. ${ }^{21}$ The coefficient of interbank is statistically significant with a positive sign and the effect is economically significant. A two-standard deviation increase in interbank (19.96\%) leads to an increase in the drawn-to-granted ratio of $1.08 \%$, which is about one-quarter of the average change during this period $(4.56 \%)$. To fully appreciate the economic significance of this result, it is worth noting that the median change in the drawn-togranted ratio between June and September 2007 is zero.

21 The number of observations in Table 5 is larger than in Table 4 because the firm-level controls included in Table 4 are not available for all the firms in the sample. Tables 3 and 4 have the same number of observations to check that the different results depend only on conditioning or not to firm observable characteristics or fixed effects. Therefore, we cannot change the sample there. In Table 6, when we analyze firm heterogeneity (Panel A), we can only use the sample with firms that have firm observable characteristics (as in Table 4), whereas when we analyze bank heterogeneity (Panel B), we can use all observations (as in Table 5). 
The results of column 1 are silent on whether the effect of a higher exposure to the interbank market is driven by a higher usage of the credit lines by firms or by a reduction in the granted amount by banks. To examine this issue in more detail, in the other columns of Table 5 we examine drawdowns and granted amounts separately. The dependent variable in column 2 is the difference between the logarithm of drawn credit in September and that in June, expressed in percentage points. We find that interbank is significantly associated with higher drawdowns. This means that firms preferentially choose to draw down on the credit lines provided by the banks with higher interbank exposure. To assess the economic significance of the coefficient of interbank in column 2, a two-standard deviation change in interbank leads to a $20 \%$ increase in the mean change in the drawn amount. Since a substantial number of credit lines are not used, with the logarithmic transformation we lose all the bank-firm relationships where the drawn amount is zero in at least one of the periods. Hence, as a robustness check, in column 3 we use an alternative definition of the change in drawdowns: the change in the drawn amounts divided by the assets of the firm in 2006. Results are consistent across different definitions.

In column 4 we examine the relation between the change in the amount of credit lines granted and the exposure to the interbank market, where the change in granted is computed as the change in logarithms between June and September 2007. Given the definition of the variable, this applies only to firm-bank relationships with an outstanding credit line before the crisis. The results show that banks with higher interbank funding do not reduce the granted amount of credit lines for existing firm-bank relationships over this period significantly more than other banks. All these results confirm the finding that the increase in the drawn-to- 
granted ratio is due to drawdowns by firms of credit lines granted by banks with higher interbank funding, rather than to a reduction in granted amounts. ${ }^{22}$

We also performed placebo tests for the main result of Table 5. Table A2 in the Appendix provides results for the change in the drawn amount and in the ratio of drawn to granted over the two quarters before the crisis (December 2006-March 2007 and March-June 2007). In these tests, the coefficient of interbank is never significant. The exposure to the interbank market is not a predictor of drawdowns outside the time of the liquidity crisis of August 2007. In Table A3 in the Appendix, we examine how the pricing of credit lines relates to interbank exposure. We find that there are no significant differences in pricing terms - both in the level before the crisis and in the change during the crisis-for credit lines granted by banks with different exposure to the interbank market. ${ }^{23}$ This suggests that firms do not draw down on the credit lines granted by banks with higher interbank exposure because the credit lines granted by these banks are cheaper before the crisis, or because they become cheaper during the first quarter of the crisis. ${ }^{24}$

${ }^{22}$ Also note that (in Table 5) the coefficient of $R O A$ is negative and significant across the first three columns (and not significant in the fourth column). This finding suggests that drawdowns are associated with banks with lower fundamentals, which is consistent with the theoretical literature that focuses on runs based on bank fundamentals (Rochet and Vives, 2004; Goldstein and Pauzner, 2005; Allen, Carletti, Goldstein, and Leonello, 2013).

${ }^{23}$ Data on interest rates come from a subsection of the Credit Register that covers more than $80 \%$ of total bank lending in Italy. We winsorize the two dependent variables (levels in June and changes in September-June) at $5 \%$. Results are similar if we do not winsorize.

${ }^{24}$ We also run the main regressions in Table 5 including the level of interest rates on the credit lines and their initial size among the control variables and results are very similar. In addition, results of Table 5 are very similar if we measure interbank as the exposure to interbank borrowing in December 2006. The correlation between the variable interbank calculated in June 2007 and in December 2006 is 0.899. 
TABLE 5 about here

\subsection{Heterogeneous effects on firm and bank characteristics}

In the previous section we have shown that firms on average draw down more from banks with higher interbank funding. In this section we explore whether this average effect is heterogeneous across firms (Panel A of Table 6), and also whether it depends on other bank characteristics (Panel B of Table 6). In particular, we address two questions: first, whether the effects on the drawdown behavior associated with interbank exposure are stronger for certain firms (e.g., smaller or more leveraged) than for others; second, whether drawdowns on banks with higher interbank exposure are different depending on bank fundamentals (e.g., size or liquidity).

Panel A of Table 6 shows results of firm cross-sectional heterogeneity. We define four dummy variables that capture different aspects of a firm's financial strength with respect to leverage, liquidity, default risk, and size (high leverage, low liquidity, high risk, small). See the exact definitions in the Appendix. Each dummy equals one if the firm is above the 75th percentile for leverage and risk, and below the 25 th percentile for liquidity and size. In each column of Panel A of Table 6 we run a regression for the change in the drawn-to-granted ratio between June and September 2007 using the same specification of column 1 in Table 6, but adding an interaction term of interbank with one of the firm dummies discussed above from columns 1 to 4 (in column 5, we include all interactions). A positive and significant coefficient on the interaction term indicates that a given firm characteristic is associated with a higher effect of interbank exposure on drawdown behavior. 
Panel A of Table 6 shows that smaller and more leveraged firms draw down more from banks with high interbank funding. According to Bernanke, Gertler, and Gilchrist (1996) and Farre-Mensa and Liungqvist (2016), among many others, leverage and size are good proxies for financial constraints in firms. This is consistent with the survey-based evidence in Campello, Graham, and Harvey (2010) that shows that during the subprime crisis, chief financial officers of financially constrained firms "drew more heavily on lines of credit for fear banks would restrict access in the future.",25

Next, we turn our attention to analyze whether certain bank characteristics reduce or amplify the run by firms on credit lines granted by banks with high interbank funding. Panel B of Table 6 shows results. The regressions are the same as in column 1 of Table 6 but they now include interactions between interbank funding and bank characteristics (capital, liquidity, ROA, and $\log$ assets). Our results show that the coefficients of bank size and liquidity are significant. As for size, this means that the effect of an increase in drawdowns from banks with high interbank funding is significantly lower for bigger banks. This is consistent with larger banks being less financially constrained, as, for example, due to toobig-to-fail (TBTF) status, which implies easier access to wholesale finance (O'Hara and Shaw, 1990; Flannery and Sorescu, 1996). Firms draw down relatively less from large banks possibly because these banks are more likely to be bailed out in case of failure, or they can obtain more easily further liquidity given their TBTF status, or because they are less financially constrained. The interaction with bank liquidity is also significant and negative, which indicates that firms run more on banks that are less liquid. This finding again reinforces the idea that firms run on credit lines preferentially from more fragile banks, because these banks are more likely to cut credit in the future.

25 See also Berrospide and Meisenzahl (2015) who show that firms, in particular, smaller and more financially constrained, use credit-line drawdowns to sustain investments. 
TABLE 6 about here

All in all, Table 6 shows that the impact of interbank exposure on drawdowns on credit lines is stronger for more financially constrained firms (more leveraged and smaller) and for more financially constrained banks (less liquid and smaller), which reinforces the result of Table 5 that runs on credit lines occur more in banks with funding problems.

\subsection{Did banks with higher interbank exposure reduce credit supply?}

In this section we investigate if the freeze of the interbank market bore real consequences in terms of lending behavior by banks. Our results of the change in the granted amounts indicate that in the summer of 2007, borrowers did not experience an immediate reduction in the supply of credit lines. Here, we examine the provision of credit to new applicants between September 2007 and March 2008. We look at multiple loan applications by a firm to different banks, and analyze how the probability that a firm's loan application is granted depends on the bank's interbank borrowing. ${ }^{26}$

To assess the impact of the shock of the interbank market on credit supply, we estimate a linear probability model in which the dependent variable is equal to one if a loan application is granted from bank $j$ to firm $i$, and zero otherwise. The linear probability model

${ }^{26}$ Loan applications have been studied in the context of monetary policy transmission (Jiménez, Ongena, Peydró, and Saurina, 2012, 2014), and in the transmission of financial shocks to borrowers (Bonaccorsi di Patti and Sette, 2012; Bofondi, Carpinelli, and Sette, 2013). This measure of credit supply is unaffected by concerns about the effect of bank-firm-specific demand for credit. The intensive margin may also be affected by the problem of ever-greening or by other unobservable bank-firm characteristics. 
allows for the inclusion of firm fixed effects, which act as controls for firm unobserved characteristics. $^{27}$ The inclusion of firm fixed effects reduces the sample by more than half because it requires at least two applications by the same firm in the same period. The average number of applications per firm in September-December 2007 is 1.24, and the probability of granting an application is $27.65 \%$.

The results are reported in Table 7. We want to analyze whether higher exposure to interbank funding leads to a lower level of granting of loan applications, and study how this relation varies before and after the interbank shock. Thus, we run two sets of separate regressions, one for the applications posted before the interbank shock, and the other for the applications posted after the shock. Columns 1 and 4 of Table 7 show results of regressions not including fixed effects, whereas columns 2 and 5 show results of regressions including firm fixed effects interacted with time (month), and columns 3 and 6 show results of regressions including only firm fixed effects. For the applications posted before the shock, we find that there is no effect associated with interbank exposure. On the other hand, for the period that follows the liquidity shock of August 2007, we observe that loan applications posted to banks with higher interbank exposure are less likely to be granted. Taken together, the results of Table 7 suggest that the tensions in the interbank market in August 2007 bore consequences in terms of lending to the real sector. Banks that were more exposed to the interbank market reduced their supply of credit to new applicants.

\section{TABLE 7 about here}

${ }^{27}$ Probit or Logit models with firm fixed effects imply that a firm with all applications granted or with all applications not granted are captured by the firm fixed effects, and thus are not used in the regression. 


\subsection{Liquidity risk management: ex ante screening}

In the last section we focus on how banks manage the risk of double runs. Our results indicate that (unconditionally to firm characteristics) banks with higher pre-crisis interbank funding do not suffer larger credit-line runs than the average bank. However, from our disaggregated regressions (loan-level) we also know that conditionally on borrower (observable and unobservable) characteristics, higher interbank funding leads to larger drawdowns on credit lines.

One way to read the above results is that banks are aware of the risk of double bank runs, and are able to mitigate it by selectively offering credit lines to borrowers (on both unobservable and observable characteristics) that are less prone to drawdowns in crisis times. Therefore, a key question is whether banks with higher interbank funding take ex ante actions to contain the risk of asset-side runs.

In Table 8, we show direct evidence on this from data before the crisis. We examine the decision of a bank to grant a credit line during the months immediately preceding the liquidity shock, and show how this choice relates to a bank's exposure to the interbank market. Panel A of Table 8 is dedicated to the extensive margin, while Panel B looks at the intensive margin. In both panels, we interact interbank with firm leverage and size, because in Panel A of Table 6 we found that these two firm characteristics matter the most for drawdowns. We also control for firm fixed effects.

Columns 1 and 2 of Panel A of Table 8 indicate that on average, banks with high interbank funding grant fewer credit lines both in March and June 2007. Additionally, columns 3 through 5 show that in June, the coefficient on the interaction of interbank and firm size is negative and significant. This means that banks with higher interbank exposure 
grant relatively fewer credit lines to small firms. ${ }^{28}$ These firms are likely to be financially constrained and, according to Table 6, are more likely to draw on their credit lines when liquidity is scarce. ${ }^{29}$

In Table A4 in the Appendix, we re-run the regressions of columns 3 to 5 for March 2007. We find that the coefficient of interbank is still negative and significant, as shown also in Panel A of Table 8 column 1, but the coefficient of the interaction between small and interbank is smaller than that estimated using data from June. A possible interpretation is that in March 2007, the effects of the subprime crisis had not yet been factored in by market participants, and banks were less cautious in screening firms according to their likelihood of running on the available credit lines. In April 2007, the first signs of the subprime crisis in the U.S. began to appear, when several banks announced losses related to subprime loans and on April 2, the largest subprime lender, New Century Financial, filed for Chapter 11. Increasing concerns about future liquidity conditions might have pushed the banks with less stable funding sources to reduce their exposure to the risk of runs on the credit lines.

In Panel B of Table 8 we examine the intensive margin of the provision of credit lines, and confirm the result that the screening of firms became tighter in the months that immediately preceded the crisis. We run a set of regressions in which the dependent variable is the logarithm of the amount of the granted credit line in March (column 1) and in June (columns 2-5). We find that in March, banks were granting credit lines of similar amounts (conditional on controls), irrespectively of their exposure to the interbank market. Instead, in June, we find that banks with higher interbank funding were granting a lower amount of credit

\footnotetext{
${ }^{28}$ Note that this result is not due to a different matching between firm size and interbank, as we control for firm fixed effects.

${ }^{29}$ The coefficient on leverage also has the same interpretation, but given the standard errors, it is not statistically significant.
} 
lines. All in all, our results suggest that, the average bank is subject to a run on the credit lines but, banks with high interbank exposure, thanks to an effective liquidity risk management, do not suffer more credit-line runs than banks with lower interbank risk.

\section{Conclusions}

Banks provide liquidity not only to depositors, but also to firms via the extension of credit lines. These simultaneous activities expose banks to the risk of correlated double runs on their assets (credit lines) and on their liabilities (wholesale uninsured deposits). In this paper, we analyze the unfolding of this risk during the recent financial crisis. Relatedly, we investigate whether banks mitigate their exposure to double runs by means of ex ante liquidity risk management in the granting of credit lines. In our empirical strategy, we exploit the shock to bank funding liquidity that came from the dry-up of the European interbank market in August 2007, in conjunction with exhaustive credit-line data held at the Italian Credit Register.

After the interbank shock, looking at just the time series before and after the shock, there are sizable, aggregate double bank runs (simultaneous asset and liability runs). Moreover, we also analyze the cross-section behavior before and after the European interbank shock. In particular, we analyze whether firms draw down more in their credit lines from banks that have higher funding liquidity risk (proxied by ex ante interbank borrowing). We find that, unconditionally to any firm characteristic, ex ante interbank exposure is unrelated to ex post credit-line drawdowns. However, conditioning on firm observable and unobservable characteristics via the inclusion of firm fixed effects, firms with multiple credit lines draw 
down more ex post from interbank-exposed banks. The impact of interbank funding on drawdowns is stronger for financially constrained firms and banks. Our results suggest that firms run on banks with higher interbank funding not because their credit lines are cheaper, but in anticipation of future credit supply restrictions. In the aftermath of the crisis, banks with higher interbank funding tighten their supply of credit to new applicants more than other banks. Moreover, banks with higher pre-crisis interbank funding experience a larger drop in interbank deposits during the crisis.

As noted above, the relation between drawdowns and interbank funding is, however, present only if one controls for firm selection (by including observable and unobservable corporate borrower characteristics). This evidence suggests that banks with higher interbank funding select firms that tend to run less in the crisis. To further test this hypothesis, we analyze the period immediately before the crisis, and show that banks with higher liability risk reduce their fragility by extending fewer credit lines, especially to financially constrained firms (extensive margin) that tend to run more in crisis times. Moreover, conditional on extending a line, banks with higher liability risk offer lower amounts (intensive margin). These results suggest ex ante screening on both observable and unobservable borrower characteristics, thus mitigating ex post (crisis) liquidity risk. In fact, our results show that such ex ante liquidity risk management neutralizes the cross-sectional effect of double runs during the crisis. That is, our findings imply that such liquidity risk management is effective in that banks with higher interbank risk do not suffer more credit-line runs than banks with lower interbank risk.

Taken together, the above results are evidence of effective liquidity risk management by banks, and are inconsistent with the prevailing view in banking that predicts risk shifting (e.g., by minimizing risk management) by more fragile banks. Our findings are more in line with the idea that financial institutions with more fragile sources of finance select assets with 
lower liquidity risk (Hanson, Shleifer, Stein, and Vishny, 2015). Considering that the provision of liquidity to both firms and depositors is at the heart of the banking business, we contribute to the theory of banking by showing that asset and liability liquidity risk in banks becomes correlated in times of crisis, and that there is liquidity risk management by banks.

Our results bear important implications for prudential policy. A key component of the new Basel III framework is the introduction of liquidity requirements, which penalize both credit-line provision and interbank funding. In this paper, we show that both items are subject to simultaneous runs. Therefore, our results suggest that the new liquidity requirements for credit lines and interbank funding are important. But our results also suggest that these requirements should not be set independently because the risk of wholesale funding and credit-line withdrawals are correlated. Moreover, our results suggest that banks are aware of this risk and actively manage it. Since risk mitigation occurs by selecting firms along observed and unobserved characteristics, the design of prudential supervision should rely on evidence from exhaustive micro data on credit lines. 


\section{Appendix}

\section{Table A1}

Description of variables.

The table describes the main dependent and control variables we use in the paper.

\begin{tabular}{|c|c|c|}
\hline Credit- line variables & Description & Source \\
\hline$\Delta$ Drawn/Granted & $\begin{array}{l}\text { Change in the ratio of drawn to granted credit line, in } \\
\text { percentage }\end{array}$ & Central Credit Register \\
\hline$\Delta$ Log Drawn & $\begin{array}{l}\text { Change in the logarithm of drawn amount of credit line, } \\
\text { in percentage }\end{array}$ & Central Credit Register \\
\hline$\Delta$ Log Granted & $\begin{array}{l}\text { Change in the logarithm of credit line granted, in } \\
\text { percentage }\end{array}$ & Central Credit Register \\
\hline$\Delta$ Drawn/Assets & $\begin{array}{l}\text { Change in the ratio of drawn amount of credit line to firm } \\
\text { assets, in percentage }\end{array}$ & Central Credit Register \\
\hline Cost of credit & $\begin{array}{l}\text { Interest rate gross of fees and commissions, paid on each } \\
\text { credit line, in percentage }\end{array}$ & Central Credit Register \\
\hline \multicolumn{3}{|c|}{ Relationship-level controls } \\
\hline Share of credit & $\begin{array}{l}\text { Share of credit of bank } j \text { out of total credit provided to } \\
\text { firm } i\end{array}$ & Central Credit Register \\
\hline Drawn/Granted & $\begin{array}{l}\text { Drawn-to-granted ratio of credit line granted by bank } j \text { to } \\
\text { firm } i \text {, in percentage }\end{array}$ & Central Credit Register \\
\hline Past-due & $\begin{array}{l}\text { Dummy variable equal to } 1 \text { if firm } i \text { had past due loans } \\
\text { with bank } j\end{array}$ & Central Credit Register \\
\hline \multicolumn{3}{|l|}{ Firm characteristics } \\
\hline Leverage & $\begin{array}{l}\text { Long-term debt by banks and other providers of funds } \\
\text { and short-term debt by banks to asset ratio, in percentage }\end{array}$ & Cerved \\
\hline Risk & $\begin{array}{l}Z \text {-score. It measures the likelihood of a firm's default } \\
\text { within one year (Altman, 1968). The score takes values } \\
\text { between } 1 \text { (least likely to default) and } 9 \text { (most likely to } \\
\text { default) }\end{array}$ & Cerved \\
\hline Liquidity & $\begin{array}{l}\text { Sum of cash and equivalents divided by total assets, in } \\
\text { percentage }\end{array}$ & Cerved \\
\hline Size & Total assets in millions of euros & Cerved \\
\hline \multicolumn{3}{|l|}{ Bank characteristics } \\
\hline Interbank & $\begin{array}{l}\text { Ratio of total borrowing from other banks to total assets, } \\
\text { inclusive of deposits and repos from other banks, } \\
\text { exclusive of deposits from the ECB or other national } \\
\text { central banks, in percentage }\end{array}$ & Supervisory Reports \\
\hline Liquidity & $\begin{array}{l}\text { Sum of cash holdings and sovereign bonds divided by } \\
\text { total assets, in percentage }\end{array}$ & Supervisory Reports \\
\hline Capital ratio & $\begin{array}{l}\text { Equity (shares subscribed, book value of equity plus } \\
\text { retained earnings) divided by total assets, in percentage }\end{array}$ & Supervisory Reports \\
\hline ROA & Net income divided by total assets, in percentage & Supervisory Reports \\
\hline Log assets & Logarithm of total assets & Supervisory Reports \\
\hline Mutual bank & $\begin{array}{l}\text { Dummy equal to one if the bank is a mutual financial } \\
\text { institution }\end{array}$ & Supervisory Reports \\
\hline \multicolumn{3}{|l|}{ Loan applications } \\
\hline $\begin{array}{l}\text { Dummy for granting a } \\
\text { credit line }\end{array}$ & $\begin{array}{l}\text { Dummy equal to one if a bank posted a request of } \\
\text { information to the Credit Register about a firm and the } \\
\text { bank grants credit to the firm in the three months } \\
\text { following the request of information (multiplied by 100) }\end{array}$ & Central Credit Register \\
\hline
\end{tabular}




\section{Table A2}

Placebo tests.

This table replicates the main results of Table 5 for the regressions on the change in the ratio of drawn to granted credit lines $(\Delta$ Drawn/Granted) and the change in the logarithm of drawn credit lines $(\Delta \log ($ Drawn $))$ on data from periods before June 2007. In particular, the changes are computed over the period December 2006March 2007 (columns 1-2) and March 2007-June 2007 (columns 3-4). The interbank funding ratio (interbank) is calculated here as of December 2006. All regressions include bank controls (calculated as of December 2006), firm fixed effects and bank-firm relationship controls (calculated as of December 2006 in the regressions shown in columns 1-2 and as of March 2007 in the regressions shown in columns 3-4). All variables are defined in Table A1. Standard errors are double clustered at the bank and firm levels and are reported in parentheses. $* * *$ $\mathrm{p}<0.01, * * \mathrm{p}<0.05, * \mathrm{p}<0.1$

\begin{tabular}{lcccc}
\hline & December & 2006-March 2007 & \multicolumn{2}{c}{ March 2007-June 2007 } \\
\hline & $\begin{array}{c}(1) \\
\text { Drawn/ } \\
\text { Granted }\end{array}$ & $\Delta$ Log(Drawn) & $\begin{array}{c}(3) \\
\Delta \text { Drawn/ } \\
\text { Granted }\end{array}$ & $\begin{array}{c}(4) \\
\text { Log(Drawn) }\end{array}$ \\
\hline Interbank & & & 0.048 & -0.133 \\
& 0.034 & 0.122 & $(0.038)$ & $(0.145)$ \\
Bank controls & $(0.022)$ & $(0.083)$ & $\mathrm{Y}$ & $\mathrm{Y}$ \\
Firm FE & $\mathrm{Y}$ & $\mathrm{Y}$ & $\mathrm{Y}$ & $\mathrm{Y}$ \\
Relationship-level controls & $\mathrm{Y}$ & $\mathrm{Y}$ & $\mathrm{Y}$ & $\mathrm{Y}$ \\
Observations & $\mathrm{Y}$ & $\mathrm{Y}$ & 454,170 & 189,148 \\
$R$-squared & 448,751 & 184,592 & 0.583 & 0.593 \\
\hline
\end{tabular}

\section{Table A3}

Cost of credit lines.

This table reports regressions of the cost of credit lines in June 2007 (column 1) and the change in the cost of credit lines between September and June 2007 (column 2) as a function of the interbank funding ratio (interbank) and a set of firm fixed effects and bank controls (capital, liquidity, ROA, and size). Both dependent variables are winsorized at the 5\% level. All regressions include bank controls and firm fixed effects. All variables are defined in Table A1. Standard errors are double clustered at the bank and firm levels and are reported in parentheses. $* * *$ $\mathrm{p}<0.01, * * \mathrm{p}<0.05, * \mathrm{p}<0.1$

\begin{tabular}{lcc}
\hline & $(1)$ & $(2)$ \\
& $\begin{array}{c}\text { Cost of credit } \\
\text { in June }\end{array}$ & $\begin{array}{c}\Delta \text { Cost of credit } \\
\text { September-June }\end{array}$ \\
\hline Interbank & & \\
& 0.007 & -0.000 \\
Cost in June & $(0.013)$ & $(0.002)$ \\
& & $-0.190 * * *$ \\
Bank controls & $\mathrm{Y}$ & $(0.004)$ \\
Firm FE & $\mathrm{Y}$ & $\mathrm{Y}$ \\
Observations & 399,237 & $\mathrm{Y}$ \\
$R$-squared & 0.713 & 349,430 \\
\hline
\end{tabular}




\section{Table A4}

Liquidity risk management in March 2007: extensive margin.

The table reports a set of linear probability model regressions of the probability that a credit line is granted to a firm, as a function of the interbank funding ratio (interbank), measured as the ratio of total borrowing from other banks to total assets, and other firm-level characteristics (leverage and size) interacted with interbank. The dummy for granting a credit line takes the value of one if a bank grants a line as of March 2007. High leverage is a dummy that takes the value one if a firm's leverage is in the top quartile of the distribution. Small is a dummy that takes the value one if a firm's assets are in the bottom quartile of the distribution. In the last column we include all interactions. All regressions include bank controls, firm fixed effects, and bank-firm relationship controls (see Section 3.2). All variables are defined in Table A1. Standard errors are double clustered at the bank and firm levels and are reported in parentheses. $* * * \mathrm{p}<0.01, * * \mathrm{p}<0.05, * \mathrm{p}<0.1$

\begin{tabular}{lcccc}
\hline & \multicolumn{4}{c}{ Dummy for granting a credit line } \\
& $(1)$ & $(2)$ & $(3)$ & $(4)$ \\
\hline Interbank & $-0.788^{*}$ & $-0.780^{*}$ & $-0.786^{*}$ & $-0.778^{*}$ \\
& $(0.415)$ & $(0.417)$ & $(0.423)$ & $(0.424)$ \\
Interbank* High leverage & & -0.043 & & -0.0422 \\
& & $(0.050)$ & & $(0.0485)$ \\
Interbank* Small & & & -0.028 & -0.0241 \\
& & & $(0.095)$ & $(0.0941)$ \\
Bank controls & $\mathrm{Y}$ & $\mathrm{Y}$ & $\mathrm{Y}$ & $\mathrm{Y}$ \\
Firm FE & $\mathrm{Y}$ & $\mathrm{Y}$ & $\mathrm{Y}$ & $\mathrm{Y}$ \\
Relationship-level controls & $\mathrm{Y}$ & $\mathrm{Y}$ & $\mathrm{Y}$ \\
Observations & 569,488 & 569,488 & 569,488 & 569,488 \\
$R$-squared & 0.438 & 0.438 & 0.438 & 0.438 \\
\hline
\end{tabular}

\section{Table A5}

The shock to interbank funding: growth rates.

The table shows regressions of the change in the logarithm of interbank deposits, measured as total borrowing from other banks, as a function of a set of bank characteristics. The sample in the first three columns includes all the banks (we calculate the log of the interbank deposits +1 ). The sample in the last three columns excludes the banks with no interbank deposits. Changes are computed over the period June 2007-December 2007 for the regression in columns 1, 2, 4, and 5, and over the period December 2006-June 2007 for the regression in columns 3 and 6. Bank-level variables used in the regression shown in columns 1,2, 4 and 5 are as of June 2007, while those in columns 3 and 6 are as of December 2006. Columns 1 and 4 show Ordinary Least Squares (OLS) estimates, while columns 2, 3, 5, and 6 show Weighted Least Squares (WLS) estimates, using as weights the bank size. All variables are defined in Table A1. Robust standard errors are reported in parentheses. *** $\mathrm{p}<0.01, * * \mathrm{p}<0.05, * \mathrm{p}<0.1$

\begin{tabular}{|c|c|c|c|c|c|c|}
\hline & \multicolumn{3}{|c|}{$\Delta \log ($ Interbank+1) } & \multicolumn{3}{|c|}{$\Delta \log ($ Interbank $)$} \\
\hline & \multicolumn{2}{|c|}{$\begin{array}{l}\text { Jun 2007- } \\
\text { Dec } 2007\end{array}$} & \multirow{2}{*}{$\begin{array}{l}\text { Dec 2006- } \\
\text { Jun 2007 } \\
(3)\end{array}$} & \multicolumn{2}{|c|}{$\begin{array}{l}\text { Jun 2007- } \\
\text { Dec } 2007\end{array}$} & \multirow{3}{*}{$\begin{array}{c}\text { Dec 2006- } \\
\text { Jun } 2007 \\
(6) \\
\text { WLS }\end{array}$} \\
\hline & (1) & (2) & & (4) & (5) & \\
\hline & OLS & WLS & WLS & OLS & WLS & \\
\hline \multirow[t]{2}{*}{ Interbank } & $-3.197 * * *$ & $-2.374 * * *$ & -0.356 & $-4.235 * * *$ & $-2.454 * * *$ & -0.368 \\
\hline & $(0.875)$ & $(0.701)$ & $(0.383)$ & $(1.152)$ & $(0.722)$ & $(0.391)$ \\
\hline \multirow[t]{2}{*}{ Liquidity } & $-0.877 * * *$ & -1.183 & 0.684 & $-2.442 * *$ & -1.495 & 0.365 \\
\hline & $(0.334)$ & $(0.835)$ & $(1.252)$ & $(1.122)$ & $(0.967)$ & (1.524) \\
\hline \multirow[t]{2}{*}{ Capital ratio } & -0.717 & $-5.620 * * *$ & $3.935^{*}$ & -1.395 & $-5.625^{* * *}$ & $4.024^{*}$ \\
\hline & $(0.617)$ & $(1.495)$ & $(2.088)$ & $(2.501)$ & $(1.541)$ & $(2.298)$ \\
\hline \multirow[t]{2}{*}{ ROA } & -4.756 & 4.176 & $-29.55 * * *$ & 5.550 & 6.673 & $-27.75 * * *$ \\
\hline & $(5.117)$ & $(9.262)$ & $(9.507)$ & (13.53) & $(9.635)$ & $(10.29)$ \\
\hline \multirow[t]{2}{*}{ Log assets } & 2.289 & $-9.392 * *$ & $7.545^{* *}$ & -3.096 & $-10.78 * * *$ & $7.410 * *$ \\
\hline & $(2.499)$ & $(3.678)$ & $(3.166)$ & $(6.364)$ & $(3.870)$ & $(3.348)$ \\
\hline \multirow[t]{2}{*}{ Mutual bank } & 3.173 & -28.29 & -4.050 & -2.586 & -24.39 & -8.519 \\
\hline & $(8.629)$ & (17.96) & (14.70) & $(21.33)$ & (19.98) & $(17.32)$ \\
\hline Observations & 531 & 531 & 529 & 413 & 413 & 416 \\
\hline$R$-squared & 0.059 & 0.356 & 0.107 & 0.031 & 0.283 & 0.065 \\
\hline
\end{tabular}




\section{References}

Acharya, V. V., Almeida, H., Campello, M., 2013. Aggregate risk and the choice between cash and lines of credit. Journal of Finance 68, 2059-2116.

Acharya, V. V., Almeida, H., Ippolito, F., Perez, A., 2014. Credit lines as monitored liquidity insurance: Theory and evidence. Journal of Financial Economics 112, 287-319.

Allen, F., Carletti, E., Goldstein, I., Leonello, A., 2013. Government guarantees and financial stability. Unpublished working paper. University of Pennsylvania.

Altman, E. I., 1968. Financial ratios, discriminant analysis and the prediction of corporate bankruptcy. Journal of Finance 23, 589-609.

Bernanke, B. S., Gertler, M., Gilchrist, S., 1996. The flight to quality and the financial accelerator. Review of Economics and Statistics 78, 1-15.

Berrospide, J. M., Meisenzahl, R., 2015. The real effects of credit line drawdowns. Finance and Economics Discussion Series 2015-007. Board of Governors of the Federal Reserve System (U.S.).

Bofondi, M., Carpinelli, L., Sette, E., 2013. Credit supply during a sovereign crisis. Bank of Italy Temi di Discussione No. 909.

Bonaccorsi di Patti, E., Sette, E., 2012. Bank balance sheets and the transmission of financial shocks to borrowers: Evidence from the 2007-2008 crisis. Bank of Italy Temi di Discussione No. 848.

Brown, M., Guin, B., Morkoetter, S., 2014. Deposit withdrawals from distressed commercial banks. Unpublished working paper. University of St. Gallen.

Brunnermeier, M., 2009. Deciphering the liquidity and credit crunch 2007-08. Journal of Economic Perspectives 23, 77-100. 
Calomiris, C. W., Kahn, C. M., 1991. The role of demandable debt in structuring optimal banking arrangements. American Economic Review 81, 497-513.

Campello, M., Graham, J. R., Harvey, C. R., 2010. The real effects of financial constraints: Evidence from a financial crisis. Journal of Financial Economics 97, 470-487.

Cingano, F., Manaresi, M., Sette, E., 2013. Does credit crunch investment down? Unpublished working paper. Universita' Politecnica Marche.

Cornett, M. M., McNutt, J. J., Strahan, P. E., Tehranian, H., 2011. Liquidity risk management and credit supply in the financial crisis. Journal of Financial Economics 101, 297-312.

Dell'Ariccia, G., Marquez, R., 2006. Lending booms and lending standards. Journal of Finance 61, 2511-2546.

Diamond, D. W., 1984. Financial intermediation and delegated monitoring. Review of Economic Studies 51, 393-414.

Diamond, D. W., Dybvig, P. H., 1983. Bank runs, deposit insurance, and liquidity. Journal of Political Economy 91, 401-419.

Diamond, D. W., Rajan, R. G., 2001. Banks and liquidity. American Economic Review 91, $422-425$.

European Central Bank, 2012. Changes in bank financing patterns. ECB-Germany, Frankfurt. Farre-Mensa, J., Ljungqvist, A., 2016. Do measures of financial constraints measure financial constraints? Review of Financial Studies 29, 271-308.

Flannery, M. J., Sorescu, S. M., 1996. Evidence of bank market discipline in subordinated debenture yields: 1983-1991. Journal of Finance 51, 1347-1377.

Freixas, X., Rochet, J. C., 2008. Microeconomics of Banking. MIT Press, Boston, MA. 
Freixas, X., Laeven, L., Peydró, J.L., 2015. Systemic Risk, Crises and Macroprudential Policy. MIT Press, Boston, MA.

Gatev, E., Strahan, P. E., 2006. Banks' advantage in hedging liquidity risk: Theory and evidence from the commercial paper market. Journal of Finance 61, 867-892.

Gatev, E., Schuermann, T., Strahan, P. E., 2009. Managing bank liquidity risk: How depositloan synergies vary with market conditions. Review of Financial Studies 22, 995-1020.

Gennaioli, N., Shleifer, A., Vishny, R. W., 2013. A model of shadow banking. Journal of Finance 68, 1331-1363.

Goldstein, I., Pauzner, A., 2005. Demand-deposit contracts and the probability of bank runs. Journal of Finance 60, 1293-1327.

Gorton, G., 2012. Misunderstanding Financial Crises: Why We Don’t See Them Coming. Oxford University Press, Oxford, UK.

Gorton, G., Metrick, A., 2012. Securitized banking and the run on repo. Journal of Financial Economics 104, 425-451.

Gorton, G., Pennacchi, G., 1990. Financial intermediaries and liquidity creation. Journal of Finance 45, 49-71.

Hanson, S. G., Shleifer, A., Stein, J. C., Vishny, R. W., 2015. Banks as patient fixed- income investors. Journal of Financial Economics 117, 449-469.

Ivashina, V., Scharfstein, D., 2010. Bank lending during the financial crisis of 2008. Journal of Financial Economics 97, 319-338.

Iyer, R., Peydró, J. L., 2011. Interbank contagion at work: Evidence from a natural experiment. Review of Financial Studies 24, 1337-1377. 
Iyer, R., Peydró, J. L., da-Rocha-Lopes, S., Schoar, A., 2014. Interbank liquidity crunch and the firm credit crunch: Evidence from the 2007-2009 crisis. Review of Financial Studies 27, $347-372$.

Iyer, R., Puri, M., 2012. Understanding bank runs: The importance of depositor-bank relationships and networks. American Economic Review 102, 1414-1445.

Iyer, R., Puri, M., Ryan, N., 2015. A tale of two runs: depositor responses to bank solvency risk. Journal of Finance, forthcoming.

Jimenez, G., Ongena, S., Peydró, J. L., Saurina, J., 2014. Hazardous times for monetary policy: What do twenty-three million bank loans say about the effects of monetary policy on credit risk-taking? Econometrica $82,463-505$.

Jiménez, G., Ongena, S., Peydró, J. L., Saurina, J., 2012. Credit supply: Identifying balancesheet channels with loan applications and granted loans. American Economic Review 102, $2301-2326$.

Kashyap, A. K., Rajan, R., Stein, J. C., 2002. Banks as liquidity providers: An explanation for the coexistence of lending and deposit-taking. Journal of Finance 57, 33-73.

Kelly, M., Gráda, C. Ó., 2000. Market contagion: Evidence from the panics of 1854 and 1857. American Economic Review 90, 1110-1124.

Khwaja, A. I., Mian, A., 2008. Tracing the impact of bank liquidity shocks: Evidence from an emerging market. American Economic Review 98, 1413-1442.

O'Hara, M., Shaw, W., 1990. Deposit insurance and wealth effects: The value of being "too big to fail." Journal of Finance 45, 1587-1600.

Rajan, R., 2011. Fault Lines: How Hidden Fractures Still Threaten the World Economy. Princeton University Press, Princeton, NJ. 
Rochet, J. C., Vives, X., 2004. Coordination failures and the lender of last resort: Was Bagehot right after all? Journal of the European Economic Association 2, 1116-1147.

Santos, J., 2014. Combining deposit taking with credit line provision and the risk of concurrent runs by depositors and firms. Unpublished working paper. Federal Reserve Bank of New York.

Schnabl, P., 2012. The international transmission of bank liquidity shocks: Evidence from an emerging market. Journal of Finance 67, 897-932.

Stein, J., 2012. Monetary policy as financial-stability regulation. Quarterly Journal of Economics 127, 57-95. 
Fig. 1. Interbank spreads on euro market (Euribor - Eurepo). The figure shows the series of spreads between the Euribor (Euribor is the average interest rate for unsecured Euro term deposits, the reference rate in the short-term unsecured interbank market) for three different maturities and the corresponding Eurepo (the average interest rate for secured money market transactions in the euro area). Values are reported in basis points (bp). Source: Thomson Datastream.

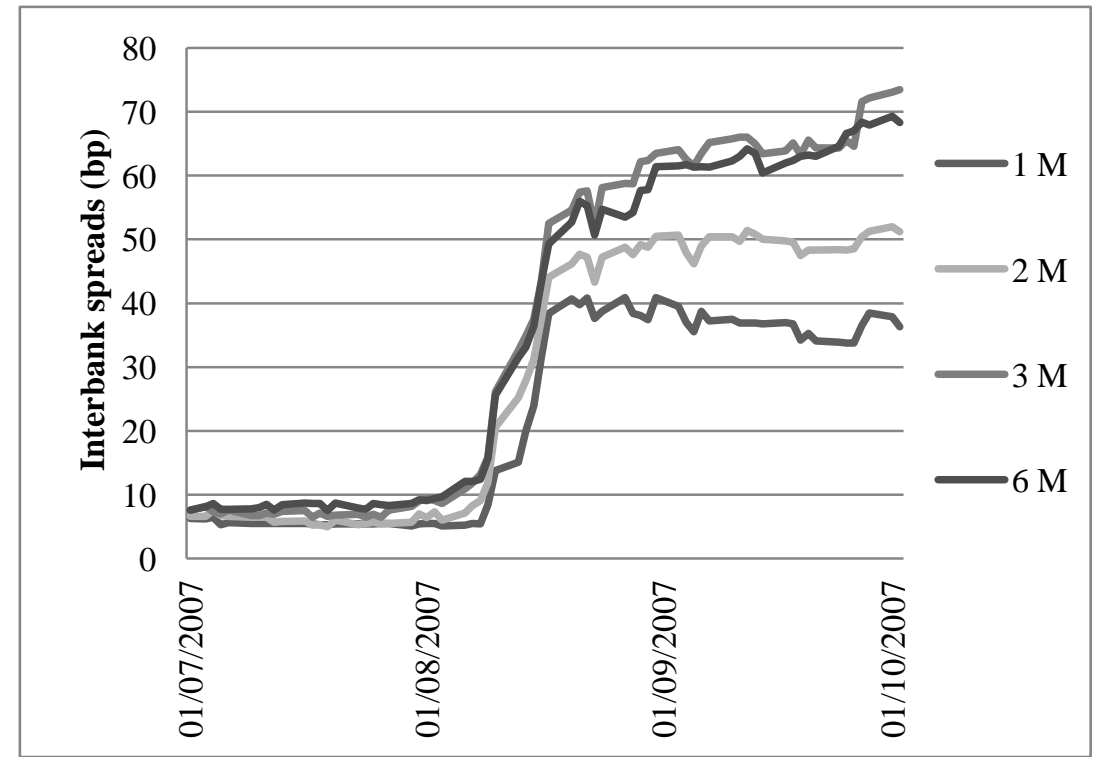




\section{Table 1}

Descriptive statistics.

The table shows descriptive statistics of the main variables employed in our analysis. The main sample covers the period June-September 2007, and it contains 472,153 bank-firm relationships reported in the Italian Credit Register. The sample includes only firms that as of June 2007 had at least two outstanding credit lines granted by different banks. Bank characteristics are calculated by weighting each bank by its size. Panel A reports the evidence on double runs looking at the changes in both credit lines and interbank deposits during and before the crisis. Panel B reports the descriptive statistics of the other variables used in the paper. All variables are defined in Table A1.

Panel A: Evidence on double runs

\begin{tabular}{|c|c|c|c|c|}
\hline & Mean & Median & St. dev. & Observations \\
\hline \multicolumn{5}{|l|}{ Crisis } \\
\hline$\Delta$ Log Drawn Jun/Sep $2007(\%)$ & 16.70 & 5.13 & 133.50 & 203,018 \\
\hline$\Delta$ Drawn/Granted Jun/Sep 2007 (\%) & 4.56 & 0.00 & 38.27 & 472,153 \\
\hline$\Delta$ Log Granted Jun/Sep 2007 (\%) & 0.75 & 0.00 & 36.75 & 472,153 \\
\hline$\Delta$ Log Interbank funding Jun/Dec $2007(\%)$ & -22.10 & -19.14 & 48.95 & 413 \\
\hline$\Delta$ Interbank funding/Assets Jun-Dec $2007(\%)$ & -3.48 & -2.72 & 5.53 & 531 \\
\hline \multicolumn{5}{|l|}{ Pre-crisis } \\
\hline$\Delta$ Drawn/Granted Mar/Jun 2007 (\%) & -0.21 & 0.00 & 36.76 & 455,545 \\
\hline$\Delta$ Log Drawn Mar/Jun $2007(\%)$ & 2.04 & 1.03 & 134.51 & 189,148 \\
\hline$\Delta$ Log Granted Mar/Jun 2007 (\%) & 0.05 & 0.00 & 37.63 & 456,304 \\
\hline$\Delta$ Log Interbank funding Jun 2007/Dec $2006(\%)$ & 13.63 & 15.26 & 41.23 & 416 \\
\hline$\Delta$ Interbank funding/Assets Jun 2007-Dec $2006(\%)$ & 2.25 & 1.30 & 2.63 & 529 \\
\hline
\end{tabular}


Panel B: Descriptive statistics of other variables

\begin{tabular}{|c|c|c|c|c|}
\hline & Mean & Median & St. dev. & Observations \\
\hline \multicolumn{5}{|l|}{ Other credit-line variables } \\
\hline$\Delta$ Drawn/Assets Jun/Sep $2007(\%)$ & 0.16 & 0.00 & 1.77 & 462,302 \\
\hline$\Delta$ Drawn/Assets Mar/Jun $2007(\%)$ & -0.01 & 0.00 & 2.83 & 439,642 \\
\hline$\Delta$ Cost of credit Jun/Sep $2007(\%)$ & 0.10 & 0.23 & 2.04 & 349,430 \\
\hline Cost of credit June $2007(\%)$ & 11.14 & 9.82 & 4.73 & 399,237 \\
\hline \multicolumn{5}{|l|}{ Relationship-level controls } \\
\hline Share of credit June $2007(\%)$ & 26.72 & 21.42 & 19.80 & 472,153 \\
\hline Drawn/Granted June 2007 (\%) & 34.62 & 3.28 & 47.13 & 472,153 \\
\hline Dummy past-due in June 2007 & 0.03 & 0.00 & 0.18 & 472,153 \\
\hline \multicolumn{5}{|l|}{ Firm characteristics } \\
\hline Leverage $(\%)$ & 26.29 & 25.02 & 21,98 & 132,148 \\
\hline Risk & 5.59 & 5.00 & 6.46 & 132,016 \\
\hline Liquidity (\%) & 6.85 & 2.85 & 9.50 & 125,055 \\
\hline Size & 9.86 & 2.13 & 273.13 & 132,439 \\
\hline \multicolumn{5}{|l|}{ Bank characteristics } \\
\hline Interbank $(\%)$ & 13.36 & 13.04 & 9.98 & 531 \\
\hline Liquidity (\%) & 6.22 & 4.69 & 5.04 & 531 \\
\hline Capital ratio (\%) & 7.49 & 7.90 & 2.73 & 531 \\
\hline ROA $(\%)$ & 1.42 & 1.06 & 0.90 & 531 \\
\hline Log assets & 10.95 & 11.62 & 2.31 & 531 \\
\hline Mutual bank (dummy) & 0.09 & 0.00 & 0.29 & 531 \\
\hline \multicolumn{5}{|l|}{ Loan applications } \\
\hline Dummy for granting a credit line post-crisis $(\%)$ & 27.65 & 0.00 & 44.73 & 188,408 \\
\hline Dummy for granting a credit line pre-crisis $(\%)$ & 27.57 & 0.00 & 44.68 & 247,842 \\
\hline
\end{tabular}




\section{Table 2}

The shock to interbank funding.

The table shows regressions of the change in the interbank funding ratio (interbank), measured as the ratio of total borrowing from other banks to total assets, as a function of a set of bank characteristics. Changes are computed over the period June 2007-December 2007 for the regression in column 1, and over the period December 2006-June 2007 for the regression in column 2. The sample in column 1 includes 531 banks operating in Italy, while that in column 2 includes 529 banks, because 2 banks started operating in 2007 and did not post a balance sheet in December 2006. All variables are defined in Table A1. Bank-level variables used in the regression shown in column 1 are as of June 2007, while those in column 2 are as of December 2006. Robust standard errors are reported in parentheses. $* * * \mathrm{p}<0.01, * * \mathrm{p}<0.05, * \mathrm{p}<0.1$

\begin{tabular}{lcc}
\hline & \multicolumn{2}{c}{$\Delta$ Interbank } \\
\cline { 2 - 3 } & Jun 2007- Dec 2007 & Dec $2006-$ Jun 2007 \\
& & \\
Interbank & $-0.189^{* *}$ & -0.002 \\
& $(0.092)$ & $(0.103)$ \\
Liquidity & $-0.027 * * *$ & 0.0159 \\
& $(0.009)$ & $(0.012)$ \\
Capital ratio & -0.033 & -0.059 \\
& $(0.026)$ & $(0.070)$ \\
ROA & -0.111 & 0.169 \\
& $(0.156)$ & $(0.441)$ \\
Log assets & 0.018 & $0.262 *$ \\
& $(0.132)$ & $(0.139)$ \\
Mutual bank & $-0.505^{* *}$ & -0.365 \\
& $(0.239)$ & $(0.317)$ \\
Observations & 531 & 529 \\
$R$-squared & 0.132 & 0.075 \\
\hline
\end{tabular}




\section{Table 3}

Runs on credit lines unconditional to firm characteristics.

Panel A contains two regressions of the change in the drawn-to-granted ratio over the period June-September 2007, as a function of the interbank funding ratio (interbank), measured as the ratio of total borrowing from other banks to total assets, and bank controls, which include liquidity, capital ratio, ROA, size, and a dummy for mutual banks. Column 1 shows Ordinary Least Squares (OLS) estimates, while column 2 shows Weighted Least Squares (WLS) estimates, using as weights the logarithm of granted amount of credit line. The sample includes 414,386 bank-firm relationships from the Italian Credit Register. Panel B shows regressions of the change in the logarithms of drawn amount of all outstanding credit lines at the bank level as a function of the bank controls listed above. Changes are computed over the period June 2007-September 2007 for the regression shown in column 1 ("After the shock"), and over the period March 2007-June 2007 for the regression shown in column 2 ("Before the shock"). Bank-level variables used in the regression shown in column 1 are as of June 2007, while those in column 2 are as of December 2006. All variables are defined in Table A1. Robust standard errors are reported in parentheses. $* * * \mathrm{p}<0.01, * * \mathrm{p}<0.05, * \mathrm{p}<0.1$

Panel A: Loan-level regressions

\begin{tabular}{lcc}
\hline & \multicolumn{2}{c}{$\Delta$ Drawn/Granted } \\
\cline { 2 - 3 } & $(1)$ & $(2)$ \\
& OLS & WLS \\
\hline Interbank & -0.006 & -0.006 \\
& $(0.015)$ & $(0.014)$ \\
Bank controls & $\mathrm{Y}$ & $\mathrm{Y}$ \\
Observations & 414,386 & 414,386 \\
$R$-squared & 0.000 & 0.000 \\
\hline
\end{tabular}

Panel B: Aggregate bank level regressions

\begin{tabular}{lcc}
\hline & \multicolumn{2}{c}{$\Delta$ Drawdowns } \\
\cline { 2 - 3 } & $(1)$ & $(2)$ \\
& After the shock & Before the shock \\
\hline Interbank & 0.002 & 0.001 \\
& $(0.008)$ & $(0.005)$ \\
Bank controls & $\mathrm{Y}$ & $\mathrm{Y}$ \\
Observations & 538 & 538 \\
$R$-squared & 0.070 & 0.102 \\
\hline
\end{tabular}




\section{Table 4}

Runs on credit lines conditional to firm characteristics.

This table contains a set of regressions of the change in the drawn-to-granted ratio over the period JuneSeptember 2007, as a function of the interbank funding ratio (interbank), measured as the ratio of total borrowing from other banks to total assets and bank controls in columns 1 and 4 . We include firm controls and bank-firm relationship controls (see Section 3.2) in columns 2 and 5. We include also firm fixed effects in columns 3 and 6. Columns 1-3 show Ordinary Least Squares (OLS) estimates, while columns 4-6 show Weighted Least Squares (WLS) estimates, using as weights the logarithm of granted amount of credit line. All variables are defined in Table A1. Standard errors are double clustered at the bank and firm levels and are reported in parentheses. $* * * \mathrm{p}<0.01, * * \mathrm{p}<0.05, * \mathrm{p}<0.1$

\begin{tabular}{|c|c|c|c|c|c|c|}
\hline & \multicolumn{6}{|c|}{$\Delta$ Drawn/Granted } \\
\hline & (1) & $\begin{array}{l}(2) \\
\text { OLS }\end{array}$ & (3) & (4) & $\begin{array}{r}(5) \\
\text { WLS } \\
\end{array}$ & (6) \\
\hline Interbank & $\begin{array}{c}-0.006 \\
(0.015)\end{array}$ & $\begin{array}{c}0.023 \\
(0.020)\end{array}$ & $\begin{array}{c}0.048 * * \\
(0.022)\end{array}$ & $\begin{array}{l}-0.006 \\
(0.014)\end{array}$ & $\begin{array}{c}0.023 \\
(0.019)\end{array}$ & $\begin{array}{c}0.046 * * \\
(0.021)\end{array}$ \\
\hline Firm leverage & & $\begin{array}{c}0.259 * * * \\
(0.007)\end{array}$ & & & $\begin{array}{c}0.250 * * * \\
(0.007)\end{array}$ & \\
\hline Firm risk & & $\begin{array}{c}4.611 * * * \\
(0.387)\end{array}$ & & & $\begin{array}{c}4.421 * * * \\
(0.357)\end{array}$ & \\
\hline Firm liquidity & & $\begin{array}{c}-0.302 * * * \\
(0.012)\end{array}$ & & & $\begin{array}{c}-0.299 * * * \\
(0.012)\end{array}$ & \\
\hline Firm size & & $\begin{array}{c}-1.307 * * * \\
(0.063)\end{array}$ & & & $\begin{array}{c}-1.266 * * * \\
(0.067)\end{array}$ & \\
\hline Bank controls & Y & Y & Y & Y & Y & $\mathrm{Y}$ \\
\hline Firm FE & $\mathrm{N}$ & $\mathrm{N}$ & $\mathrm{Y}$ & $\mathrm{N}$ & $\mathrm{N}$ & $\mathrm{Y}$ \\
\hline Relationship-level controls & $\mathrm{N}$ & $\mathrm{Y}$ & $\mathrm{Y}$ & $\mathrm{N}$ & $\mathrm{Y}$ & $\mathrm{Y}$ \\
\hline Observations & 414,386 & 414,386 & 414,386 & 414,386 & 414,386 & 414,386 \\
\hline$R$-squared & 0.000 & 0.143 & 0.536 & 0.000 & 0.140 & 0.532 \\
\hline
\end{tabular}




\section{Table 5}

Run on credit lines: full-fledged regressions with firm fixed effects.

The table shows a set of regressions based on the specifications presented in Section 3.2. The main variable of interest is the interbank funding ratio (interbank), measured as the ratio of total borrowing from other banks to total assets. The dependent variables are the change in the ratio of drawn to granted credit lines (column 1), the change in the logarithm of drawn credit lines (column 2), the change in drawn credit lines normalized by firm assets (column 3), and the change in the logarithm of granted credit lines (column 4). Changes are computed over the period June 2007-September 2007. The sample includes 472,153 bank-firm relationships from the Italian Credit Register. All variables are defined in Table A1. All regressions include firm fixed effects and bank-firm relationship controls (see Section 3.2). Standard errors are double clustered at the bank and firm levels and are reported in parentheses. $* * * \mathrm{p}<0.01, * * \mathrm{p}<0.05, * \mathrm{p}<0.1$

\begin{tabular}{lcccc}
\hline & $(1)$ & $(2)$ & $(3)$ & $(4)$ \\
& $\Delta$ Drawn/ & $\Delta \log ($ Drawn $)$ & $\Delta$ Drawn/ & $\Delta$ Log(Granted) \\
& Granted & & Assets & \\
\hline \multirow{2}{*}{ Interbank } & & & & \\
& $0.054^{* *}$ & $0.163^{*}$ & $0.001^{* *}$ & -0.008 \\
Liquidity & $(0.022)$ & $(0.097)$ & $(0.001)$ & $(0.015)$ \\
& 0.055 & $0.346^{* *}$ & $0.003 * * *$ & 0.046 \\
Capital ratio & $(0.037)$ & $(0.147)$ & $(0.001)$ & $(0.036)$ \\
& 0.043 & $0.848^{* * *}$ & 0.000 & -0.068 \\
ROA & $(0.077)$ & $(0.260)$ & $(0.002)$ & $(0.043)$ \\
& $-0.645^{* *}$ & $-3.817^{* * *}$ & $-0.013 *$ & -0.033 \\
Log assets & $(0.298)$ & $(1.444)$ & $(0.008)$ & $(0.210)$ \\
& $-0.476^{* * *}$ & -0.379 & $-0.011 * *$ & $0.221 *$ \\
Mutual bank & $(0.135)$ & $(0.586)$ & $(0.004)$ & $(0.129)$ \\
Firm FE & $-1.759^{* * *}$ & $-6.332^{* *}$ & -0.032 & 0.190 \\
Relationship-level controls & $(0.535)$ & $(2.634)$ & $(0.026)$ & $(0.598)$ \\
Observations & $\mathrm{Y}$ & $\mathrm{Y}$ & $\mathrm{Y}$ & $\mathrm{Y}$ \\
$R$-squared & 472,153 & 203,018 & 462,302 & 472,153 \\
\hline
\end{tabular}




\section{Table 6}

Firm and bank heterogeneity.

Panel A shows regressions of the change in the ratio of drawn to granted credit lines on the interbank funding ratio (interbank), measured as the ratio of total borrowing from other banks to total assets, and other firm-level characteristics interacted with interbank. Changes in the ratio of drawn to granted are computed over the period June 2007-September 2007. Regressions include interactions between interbank and the following firm-level dummies: high leverage which is equal to one if firm leverage is in the top quartile of the distribution; high risk which is equal to one if a firm's Z-score is above 7; low liquidity which is equal to one if a firm's liquidity is in the bottom quartile of the distribution; small which is equal to one if a firm's assets are in the bottom quartile of the distribution. Panel B shows regressions of the change in the ratio of drawn to granted credit lines on interbank funding (interbank), measured as the ratio of total borrowing from other banks to total assets, and other bank-level characteristics interacted with interbank. Regressions include interactions between interbank and the following bank-level characteristics: liquidity, capital ratio, ROA, and size. All variables are defined in Table A1. All regressions include bank controls, firm fixed effects, and bank-firm relationship controls (see Section 3.2). The last column includes all interactions. Standard errors are double clustered at the bank and firm levels and are reported in parentheses. *** $\mathrm{p}<0.01$, ** $\mathrm{p}<0.05, * \mathrm{p}<0.1$

Panel A: Firm heterogeneity

\begin{tabular}{|c|c|c|c|c|c|}
\hline & \multicolumn{5}{|c|}{$\Delta$ Drawn/Granted } \\
\hline & (1) & (2) & (3) & $(4)$ & $(5)$ \\
\hline \multirow[t]{2}{*}{ Interbank } & $0.043 * *$ & $0.049 * *$ & $0.050 * *$ & $0.039 *$ & $0.0375^{*}$ \\
\hline & $(0.021)$ & $(0.022)$ & $(0.021)$ & $(0.022)$ & $(0.0203)$ \\
\hline \multirow[t]{2}{*}{ Interbank* High leverage } & $0.022 *$ & & & & $0.0226 *$ \\
\hline & $(0.013)$ & & & & $(0.0137)$ \\
\hline \multirow[t]{2}{*}{ Interbank* High risk } & & -0.027 & & & -0.0471 \\
\hline & & $(0.030)$ & & & $(0.0307)$ \\
\hline \multirow[t]{2}{*}{ Interbank* Low liquidity } & & & -0.008 & & -0.00583 \\
\hline & & & $(0.016)$ & & $(0.0155)$ \\
\hline \multirow[t]{2}{*}{ Interbank* Small } & & & & $0.054 * * *$ & $0.0526 * * *$ \\
\hline & & & & $(0.016)$ & $(0.0164)$ \\
\hline Bank controls & Y & $\mathrm{Y}$ & Y & $\mathrm{Y}$ & $\mathrm{Y}$ \\
\hline Firm FE & Y & Y & Y & Y & Y \\
\hline Relationship-level controls & Y & Y & Y & Y & $\mathrm{N}$ \\
\hline Observations & 414,386 & 414,386 & 414,386 & 414,386 & 414,386 \\
\hline$R$-squared & 0.561 & 0.561 & 0.561 & 0.561 & 0.561 \\
\hline
\end{tabular}

Panel B: Bank heterogeneity

\begin{tabular}{lccccc}
\hline & \multicolumn{5}{c}{$\Delta$ Drawn/Granted } \\
\cline { 2 - 6 } & $(1)$ & $(2)$ & $(3)$ & $(4)$ & $(5)$ \\
\hline Interbank & $0.073^{* * *}$ & -0.024 & $0.080^{*}$ & $0.738^{* * *}$ & $0.830^{* * *}$ \\
& $(0.024)$ & $(0.072)$ & $(0.046)$ & $(0.223)$ & $(0.290)$ \\
Interbank* Liquidity & $-0.008^{*}$ & & & & $-0.019 * * *$ \\
& $(0.004)$ & & & & $(0.005)$ \\
Interbank* Capital ratio & & 0.009 & & & $0.019 * *$ \\
& & $(0.006)$ & & & $(0.009)$ \\
Interbank* ROA & & & -0.017 & & -0.012 \\
& & & $(0.020)$ & & $(0.030)$ \\
Interbank* Size & & & & $-0.064 * * *$ & $-0.083 * * *$ \\
& & $\mathrm{Y}$ & $\mathrm{Y}$ & $(0.020)$ & $(0.023)$ \\
Bank controls & $\mathrm{Y}$ & $\mathrm{Y}$ & $\mathrm{Y}$ & $\mathrm{Y}$ & $\mathrm{Y}$ \\
Firm FE & $\mathrm{Y}$ & $\mathrm{Y}$ & $\mathrm{Y}$ & $\mathrm{Y}$ & $\mathrm{Y}$ \\
Relationship-level controls & 472,153 & 472,153 & 472,153 & 472,153 & 472,153 \\
Observations & 0.561 & 0.561 & 0.561 & 0.561 & 0.561 \\
$R$-squared & & & & & $\mathrm{Y}$ \\
& & & & & \\
\end{tabular}




\section{Table 7}

Supply of credit to new applicants.

The table shows a set of linear probability model regressions of the probability of a loan being granted before and after the liquidity shock, as a function of the interbank funding ratio (interbank), measured as the ratio of total borrowing from other banks to total assets. More precisely, we regress a dummy variable that is equal to one if a loan application is granted within 90 days, on the interbank funding ratio (interbank) of the bank that receives the application, controlling for a set of bank-level controls, and including firm-time fixed effects in columns 2 and 5, and firm fixed effects in columns 3 and 6. The regressions that refer to the period after the liquidity shock (columns 1, 2, and 3) include loan applications posted between September and December 2007. For these applications, credit is to be granted in the period September 2007-March 2008. The regressions that refer to the period before the liquidity shock (columns 4, 5, and 6) include loan applications posted between January and April 2007. For these applications, credit is to be granted in the period January 2007- July 2007. All variables are defined in Table A1. Standard errors are double clustered at the bank and firm levels, and are reported in parentheses. $* * * \mathrm{p}<0.01, * * \mathrm{p}<0.05, * \mathrm{p}<0.1$

\begin{tabular}{lcccccc}
\hline & \multicolumn{6}{c}{ Probability of a loan application being granted } \\
\cline { 2 - 7 } & $(1)$ & $\begin{array}{c}(2) \\
\text { After the shock }\end{array}$ & $(3)$ & $(4)$ & $\begin{array}{c}(5) \\
\text { Before the shock }\end{array}$ \\
\hline \multirow{2}{*}{ Interbank } & $-0.409 * * *$ & $-0.260^{* * *}$ & $-0.258^{* * *}$ & -0.083 & 0.026 & -0.004 \\
& $(0.082)$ & $(0.060)$ & $(0.060)$ & $(0.174)$ & $(0.058)$ & $(0.070)$ \\
Bank controls & $\mathrm{Y}$ & $\mathrm{Y}$ & $\mathrm{Y}$ & $\mathrm{Y}$ & $\mathrm{Y}$ & $\mathrm{Y}$ \\
Firm FE & $\mathrm{N}$ & $\mathrm{N}$ & $\mathrm{Y}$ & $\mathrm{N}$ & $\mathrm{N}$ & $\mathrm{Y}$ \\
Firm* Time FE & $\mathrm{N}$ & $\mathrm{Y}$ & $\mathrm{N}$ & $\mathrm{N}$ & $\mathrm{Y}$ & $\mathrm{N}$ \\
Observations & 188,162 & 35,054 & 95,453 & 247,704 & 52,341 & 138,738 \\
$R$-squared & 0.013 & 0.913 & 0.776 & 0.006 & 0.900 & 0.743 \\
\hline
\end{tabular}




\section{Table 8}

Screening of borrowers.

Panel A reports a set of linear probability model regressions of the probability that a credit line is granted to a firm, as a function of the interbank funding ratio (interbank), measured as the ratio of total borrowing from other banks to total assets, and other firm-level characteristics (leverage and size) interacted with interbank. The dummy for granting a credit line takes the value of one if a bank is granting a line as of March 2007 in column 1 and as of June 2007 in columns 2 through 5. Panel B reports a set of regressions where the dependent variable is the logarithm of the granted amount of credit line in March (column 1) and in June (columns 2-5), as a function of the interbank funding ratio (interbank), measured as the ratio of total borrowing from other banks to total assets and other firm-level characteristics (leverage and size) interacted with interbank. High leverage is a dummy that is equal to one if a firm's leverage is in the top quartile of the distribution. Small is a dummy that is equal to one if a firm's assets are in the bottom quartile of the distribution. In the last column we include both interactions. All variables are defined in Table A1. All regressions include bank controls, firm fixed effects, and bank-firm relationship controls (see Section 3.2). Standard errors are double clustered at the bank and firm levels and are reported in parentheses. $* * * \mathrm{p}<0.01, * * \mathrm{p}<0.05, * \mathrm{p}<0.1$

Panel A: Extensive margin

\begin{tabular}{|c|c|c|c|c|c|}
\hline & \multicolumn{5}{|c|}{ Dummy for granting a credit line } \\
\hline & \multirow{2}{*}{$\begin{array}{c}(1) \\
\text { March } 2007\end{array}$} & (2) & (3) & (4) & (5) \\
\hline & & \multicolumn{4}{|c|}{ June 2007} \\
\hline \multirow[t]{2}{*}{ Interbank } & $-0.788 *$ & $-0.283 * *$ & $-0.277 *$ & $-0.276^{*}$ & $-0.271 *$ \\
\hline & $(0.415)$ & $(0.141)$ & $(0.143)$ & $(0.143)$ & $(0.144)$ \\
\hline \multirow[t]{2}{*}{ Interbank*High leverage } & & & -0.029 & & -0.026 \\
\hline & & & $(0.032)$ & & $(0.031)$ \\
\hline \multirow[t]{2}{*}{ Interbank* Small } & & & & $-0.073 *$ & $-0.071 *$ \\
\hline & & & & $(0.038)$ & $(0.037)$ \\
\hline Bank controls & $\mathrm{Y}$ & Y & $\mathrm{Y}$ & $\mathrm{Y}$ & $\mathrm{Y}$ \\
\hline Firm FE & $\mathrm{Y}$ & Y & $\mathrm{Y}$ & $\mathrm{Y}$ & $\mathrm{Y}$ \\
\hline Relationship-level controls & $\mathrm{Y}$ & $\mathrm{Y}$ & $\mathrm{Y}$ & $\mathrm{Y}$ & $\mathrm{Y}$ \\
\hline Observations & 569,488 & 576,008 & 576,008 & 576,008 & 576,008 \\
\hline$R$-squared & 0.438 & 0.450 & 0.450 & 0.450 & 0.450 \\
\hline
\end{tabular}

Panel B: Intensive margin

\begin{tabular}{lccccc}
\hline & \multicolumn{4}{c}{ Logarithm of granted amount of credit line } \\
\cline { 2 - 6 } & $(1)$ & $(2)$ & $(3)$ & $(4)$ & $(5)$ \\
& March & & \multicolumn{2}{c}{ June 2007} \\
& 2007 & & & \\
Interbank & & & & & \\
& 0.000 & $-0.007^{* *}$ & $-0.007 * *$ & $-0.007 * *$ & $-0.007 * *$ \\
Interbank* High leverage & $(0.003)$ & $(0.003)$ & $(0.003)$ & $(0.003)$ & $(0.003)$ \\
& & & -0.001 & & -0.001 \\
Interbank* Small & & & & & $(0.001)$ \\
& & & & $0.001)$ & 0.000 \\
Bank controls & $\mathrm{Y}$ & $\mathrm{Y}$ & $\mathrm{Y}$ & $(0.002)$ & $(0.002)$ \\
Firm FE & $\mathrm{Y}$ & $\mathrm{Y}$ & $\mathrm{Y}$ & $\mathrm{Y}$ & $\mathrm{Y}$ \\
Relationship-level controls & $\mathrm{Y}$ & $\mathrm{Y}$ & $\mathrm{Y}$ & $\mathrm{Y}$ & $\mathrm{Y}$ \\
Observations & 411,392 & 414,386 & 414,386 & 414,386 & 414,386 \\
$R$-squared & 0.700 & 0.717 & 0.717 & 0.717 & 0.717 \\
\hline
\end{tabular}

